COLOGNESE, Mariângela Matarazzo Fanfa. O caso Samarco: vitimização ambiental e dano social corporativo no cenário de Mariana - uma investigação empírica a partir da perspectiva das vítimas (PARTE II). Revista Eletrônica Direito e Política, Programa de Pós-Graduação Stricto Sensu em Ciência Jurídica da UNIVALI, Itajaí, v.13, n.3, $3^{\circ}$ quadrimestre de 2018. Disponível em: www.univali.br/direitoepolitica - ISSN 1980-7791

\title{
O CASO SAMARCO: VITIMIZAÇÃO AMBIENTAL E DANO SOCIAL CORPORATIVO NO CENÁRIO DE MARIANA - UMA INVESTIGAÇÃO EMPÍRICA A PARTIR DA PERSPECTIVA DAS VÍTIMAS (PARTE II)
}

THE SAMARCO CASE: ENVIRONMENTAL VICTIMIZATION AND CORPORATE SOCIAL HARM

IN THE MARIANA SCENARIO - AN EMPIRICAL INVESTIGATION FROM THE PERSPECTIVE

OF THE VICTIMS (PART II)

\section{Mariângela Matarazzo Fanfa Colognese ${ }^{1}$}

\begin{abstract}
SUMÁRIO: Introdução; $1 \mathrm{~A}$ voz das vítimas da Samarco, Vale e BHP Billiton; $1.1 \mathrm{~A}$ ausência de vigilância e de diagnóstico: a omissão do Estado; 1.2 O conflito entre a dependência econômica da mineradora e a liberdade, e a mineração e a sociedade/meio ambiente: estados de negação; 2 A dimensão dos danos sociais; 3 Os aspectos da vitimização ambiental; Considerações finais; Referências das fontes citadas.
\end{abstract}

\section{RESUMO}

Este estudo propõe-se a compreender o fenômeno da vitimização ambiental no cenário de devastação causado pelo rompimento da barragem de Fundão, em Mariana, Minas Gerais. Esta pesquisa é de gênero empírico e de objetivo exploratório-descritivo. 0 método de abordagem é qualitativo e sua operacionalização se deu através da entrevista qualitativa semiestruturada e da observação participante. Para a análise dos dados, decidiu-se pela teoria fundamentada nos dados. A pesquisa envolveu duas etapas distintas. A primeira utilizou a investigação bibliográfica e compõe a primeira parte deste artigo. A segunda fase consiste na pesquisa qualitativa. A análise interpretativa e os resultados compõem a segunda parte deste artigo. As pessoas participantes da pesquisa são moradores de Mariana e seus subdistritos. A partir dos dados coletados, foram construídas duas categorias de análise que revelam a complexidade da vitimização na esfera ambiental. A compreensão dessa realidade e a interpretação do dano são buscadas na cena social, segundo a perspectiva de quem o vivencia. Verifica-se que a visibilização das vítimas ambientais é um fator extremamente relevante para o estudo do fenômeno, para que instrumentos jurídicos de tratamento, formas de resolução de conflitos e de respostas institucionais a essa espécie de vitimização se pautem em seus resultados.

Palavras-chave: Vitimização ambiental; dano social; dano estatal-corporativo; criminologia crítica; criminologia verde.

\section{ABSTRACT}

This study intends to understand the phenomenon of environmental victimization in the scenario of devastation caused by the rupture of the Fundão dam, in Mariana, Minas Gerais. This research is of empirical gender and exploratory-descriptive objective. The method of approach is qualitative and its operationalization occurred through the semi-

\footnotetext{
1 Mestre em Direito pelo Programa de Pós-Graduação Stricto Sensu da IMED/Passo Fundo, RS. Área de concentração: Mecanismos de Efetivação da Democracia e da Sustentabilidade. Bolsista PROSUP/CAPES. Integrante de equipe do projeto Crimes dos poderosos, dano social e discurso: análise dos processos de invisibilização e desresponsabilização. Graduada em Direito pela Universidade Luterana do Brasil - ULBRA. Email: mari.colognese@gmail.com
} 
COLOGNESE, Mariângela Matarazzo Fanfa. O caso Samarco: vitimização ambiental e dano social corporativo no cenário de Mariana - uma investigação empírica a partir da perspectiva das vítimas (PARTE II). Revista Eletrônica Direito e Política, Programa de Pós-Graduação Stricto Sensu em Ciência Jurídica da UNIVALI, Itajaí, v.13, n.3, $3^{\circ}$ quadrimestre de 2018. Disponível em: www.univali.br/direitoepolitica - ISSN 1980-7791

structured qualitative interview and participant observation. For the analysis of the data, it was decided by the grounded theory. The research involved two distinct steps. The first stage used bibliographical research and composed the first part of this article. The second phase consists in the qualitative research. The interpretive analysis and the results make up the second part of this article. The people participating in the study are residents of Mariana and its subdistricts. From the collected data, two categories of analysis were constructed that reveal the complexity of the victimization in the environmental sphere. The understanding of this reality and the interpretation of harm are sought in the social scene, according to the perspective of those who experience it. It's verified that the visualization of the environmental victims is an extremely important factor for the study of the phenomenon, so that legal instruments of treatment, forms of conflict resolution and institutional responses to this type of victimization can be based on their results.

Keywords: environmental victimization; social harm; state-corporate harm; critical criminology; green criminology.

\section{INTRODUÇÃO}

Desde o momento que se percebeu, através das questões apresentadas pelas teorias criminológicas verdes, que os danos ambientais não eram apenas eventos naturais, mas efeitos da ação/omissão humana, propugnou-se por um conhecimento capaz de expor a macrocriminalidade, os crimes dos poderosos e o crime estatal-corporativo, todos elementos que agem simbioticamente com o capitalismo e a globalização, beneficiandose dos poderes políticos. Os impactos dessas ações ou omissões sobre os seres e a natureza são devastadores e os danos são incalculáveis e exponencialmente maiores do que aqueles causados pela microcriminalidade comum.

As consequências das ofensas ambientais e a extensão dos danos sociais por elas causados são frequentemente ignorados pelos estudos criminológicos e raro é o controle social formal e informal sobre esses danos. O Estado diversas vezes facilita ou ignora tais atividades, reforçando a premissa de que essas ofensas são uma contradição, à medida que as instituições estatais encarregadas de preveni-las e puni-las podem ser as mesmas que as cometem. Em razão disso, as demandas ambientais tem suscitado da criminologia e da vitimologia uma mudança de paradigmas, exigindo-se que seu olhar se volte para os danos resultantes da degradação ambiental e para as vítimas dessas ofensas massivas.

A primeira parte deste artigo utilizou a investigação bibliográfica, dedicando-se ao enquadramento para examinar os danos sociais corporativos, com a descrição do campo da criminologia verde, incursionando no campo da vitimologia ambiental e nos danos sociais intrínsecos aos danos ambientais. A segunda parte deste estudo destina-se à pesquisa qualitativa. O objetivo é compreender o fenômeno da vitimização ambiental no cenário de Mariana/MG a partir do relato das pessoas que vivenciam em primeira mão a 
COLOGNESE, Mariângela Matarazzo Fanfa. O caso Samarco: vitimização ambiental e dano social corporativo no cenário de Mariana - uma investigação empírica a partir da perspectiva das vítimas (PARTE II). Revista Eletrônica Direito e Política, Programa de Pós-Graduação Stricto Sensu em Ciência Jurídica da UNIVALI, Itajaí, v.13, n.3, 30 quadrimestre de 2018. Disponível em: www.univali.br/direitoepolitica - ISSN 1980-7791

experiência do dano ambiental.

A pesquisa é de gênero empírico e de objetivo exploratório-descritivo. O método de abordagem é qualitativo e sua operacionalização se deu através da entrevista qualitativa semiestruturada e da observação participante. A segunda objetiva resolver a seguinte problemática: como as vítimas de Mariana significam o dano social causado pelo rompimento da barragem de Fundão? Importante ressaltar que mesmo estando ciente de que a influência do positivismo científico levou à adoção predominante na cultura jurídica brasileira da terceira pessoa, de modo a impessoalizar a linguagem, optei, neste trabalho, pelo uso da primeira pessoa. Essa escolha decorre de pelo menos duas razões: 1) a pesquisa científica possui autoria, operacionalizada através da observação participante, o que não deve ser ocultado por um subterfúgio desse tipo. Usar a linguagem impessoal incorreria na autoneutralização do cientista social e sua tentativa sincera de produzir um conhecimento científico sem se calar diante do discurso objetivo da ciência; 2) a objetividade científica, tal qual projetada pelo positivismo científico não possui comprovação empírica, de modo que existem outros critérios mais adequados para a verificação da cientificidade do trabalho qualitativo no campo das ciências sociais. Esse nível de realidade não pode ser quantificado nem reduzido em variáveis ou percebido em equações ou estatísticas. A compreensão da realidade humana vivida socialmente é o centro da sua investigação.

As pessoas participantes da pesquisa são as vítimas atingidas direta ou indiretamente pelo impacto ambiental e social por consequência do rompimento da barragem de Fundão, ou seja, habitantes da cidade de Mariana e de seus subdistritos, Bento Rodrigues e Paracatu de Baixo. O acesso às pessoas participantes da pesquisa se deu através dos movimentos sociais envolvidos no amparo aos atingidos e atingidas: o Movimento dos Atingidos por Barragens (MAB) e a Arquidiocese de Mariana.

Os sujeitos da pesquisa foram escolhidos por sua vulnerabilidade específica, que não é geralmente levada em consideração pela legislação nacional e pelas agências de aplicação da lei. Também para conhecer de que forma esse tipo específico de vítima significa o dano individual próprio e os seus reflexos na comunidade, as condutas da mineradora e do Estado, bem como a atuação das vítimas nas reivindicações por seus direitos. Diante da realidade significada pelas próprias pessoas participantes, sobressai o sofrimento social e a injustiça ambiental, onde a experiência da vitimização será construída e visibilizada a partir das distintas perspectivas de quem a experimenta e testemunha. 
COLOGNESE, Mariângela Matarazzo Fanfa. O caso Samarco: vitimização ambiental e dano social corporativo no cenário de Mariana - uma investigação empírica a partir da perspectiva das vítimas (PARTE II). Revista Eletrônica Direito e Política, Programa de Pós-Graduação Stricto Sensu em Ciência Jurídica da UNIVALI, Itajaí, v.13, n.3, $3^{\circ}$ quadrimestre de 2018. Disponível em: www.univali.br/direitoepolitica - ISSN 1980-7791

O instrumento utilizado para a coleta de dados foi a entrevista individual semiestruturada, que combinou perguntas fechadas e abertas para possibilitar ao entrevistado discorrer sobre o tema sem se prender a indagações específicas. Foram entrevistadas doze pessoas e seus depoimentos foram gravados em gravador portátil e posteriormente transcritos. O desenvolvimento do presente estudo pautou-se pela Resolução 466/2012 do Conselho Nacional de Saúde², que dispõe sobre as diretrizes e as normas regulamentadoras de pesquisa envolvendo seres humanos. $O$ projeto de pesquisa tramitou no Comitê de Ética e Pesquisa da Faculdade IMED Passo Fundo, RS, sob o código de referência CAAE: 57363716.2.0000.5319, e atendeu todas as recomendações detalhadas no parecer no 1.625.663. Em razão da privacidade e do sigilo dessas informações, os nomes das pessoas entrevistadas foram substituídos por pseudônimos, os quais indicam os heróis e as heroínas da Inconfidência Mineira.

A partir dos dados coletados, foram construídas duas categorias de análise que revelam a complexidade da vitimização na esfera ambiental: o conflito entre dependência econômica da mineradora e liberdade, emprego/mineração e sociedade/meio ambiente; e a dimensão do dano social e os aspectos da vitimização.

Para a análise dos dados, optei pela metodologia da teorização enraizada (grounded theory). A teorização enraizada ou teoria fundamentada nos dados é um método qualitativo desenvolvido por Barney Glaser e Anselm Strauss ${ }^{3}$ quando estudaram o processo da morte em ambientes hospitalares e propuseram para a análise qualitativa sistemática uma lógica própria, com a pretensão de construir conhecimentos sobre fenômenos pouco explorados, emergentes das interações humanas e significados atribuídos pelos atores sociais envolvidos.

Desse modo, ao utilizar a teoria fundamentada enquanto técnica de análise, foi possível desenvolver uma narrativa descritiva sobre o fenômeno central do estudo a partir de análises interpretativas que reconhecem as construções da realidade. O que enfatizo aqui é a análise de um processo social, sua interpretação e descrição para tornar central o estudo da ação e criar compreensões interpretativas da realidade. Assim, não pretendo que os leitores analisem minha pesquisa enquanto "teoria", obediente às normas de teorização e envolvida na sua "mística imponente" da tradição positivista objetivista.

2 BRASIL. Resolução no 466, 12 de dezembro de 2012. Dispõe sobre as diretrizes e as normas regulamentadoras de pesquisa envolvendo seres humanos. Conselho Nacional de Saúde. Brasília, 2012.

3 GLASER, Barney G.; STRAUSS, Anselm L. Awareness of dying. Chicago: Aldine, 1965; The

Discovery of grounded theory. Chicago: Aldine, 1967. 
COLOGNESE, Mariângela Matarazzo Fanfa. O caso Samarco: vitimização ambiental e dano social corporativo no cenário de Mariana - uma investigação empírica a partir da perspectiva das vítimas (PARTE II). Revista Eletrônica Direito e Política, Programa de Pós-Graduação Stricto Sensu em Ciência Jurídica da UNIVALI, Itajaí, v.13, n.3, $3^{\circ}$ quadrimestre de 2018. Disponível em: www.univali.br/direitoepolitica - ISSN 1980-7791

O conteúdo da minha teorização é narrativo descritivo, sendo, portanto, uma definição alternativa de teoria porque enfatiza a compreensão e não a explicação. Construí um conhecimento para compreender um fenômeno pouco explorado (vitimização ambiental) e o sofrimento social causado pela degradação ambiental, observando-o enquanto acontece na cena social.

Não obstante a crescente prevalência das demandas ambientais, raras são as investigações empíricas no Brasil, no campo do direito, que evidenciem a natureza complexa e interdisciplinar da vitimização ambiental. Por isso, é um desafio inovador desenvolver abordagens metodológicas para extrair dados deste grupo diverso, na esteira de outros autores e autoras que vêm desenvolvendo trabalhos desse tipo no exterior.

\section{A VOZ DAS VÍTIMAS DA SAMARCO, VALE E BHP BILLITON}

Embora se tenha ciência de que a criminologia não possa ser considerada apenas para priorizar o estudo de ofensas contra a espécie humana, mas uma dimensão de bens ecológicos tão valiosos como esta, opta-se pelo estudo das vítimas humanas para que se possa perceber, através das suas narrativas, a dimensão dos prejuízos físico-naturais e dos danos sociais causados por ofensas que causam degradação do meio ambiente.

Dirigi-me ao Estado de Minas Gerais com vários questionamentos: o que está acontecendo em Mariana? A violação de direitos humanos perpetrada pela ação da Samarco e pela omissão do Estado? Crime ambiental? Danos ambientais? Danos sociais? Greenwashing ${ }^{4}$ ? A existência de todos esses elementos a um só tempo é perceptível.

Ao adentrar no espaço aéreo da capital mineira, percebi, através da janela do avião, inúmeras lavras a céu aberto, de tamanhos consideráveis. No trajeto de Belo Horizonte para Mariana $(117 \mathrm{~km})$, visualizei uma paisagem rica, mas mal tratada pela mineração, onde a vegetação reflete o resultado da atuação humana sobre o meio ambiente. Destacam-se áreas em que as lavras foram substituídas pela cobertura vegetal, pois na medida em que o potencial exploratório se esgotou nos terraços, eles foram abandonados $^{5}$. Isso comprova o que é notório no setor: a mineração é o propulsor da

\footnotetext{
${ }^{4}$ A sustentabilidade é o slogan de grandes poluidores para disfarçar a produção e a reprodução das suas atividades ambientalmente nocivas. Enganar os consumidores em relação aos benefícios ambientais de um produto ou negócio tornou-se um novo padrão de marketing e os "greenwashers" levam essa prática comercial ao extremo, pois assim tornam mais aceitável uma atividade que é inevitavelmente perigosa para o meio ambiente e para as pessoas.

${ }^{5}$ Fabiano Reis Silva, ao traçar zonas de interesse turístico e caracterizar os aspectos geológicos e de evolução geomorfológica, potencialidades e limitações do Quadrilátero Ferrífero, ressalta que a intensa exploração mineral descaracterizou uma parcela significativa das serras do Quadrilátero Ferrífero, deformando-as pelas
} 
COLOGNESE, Mariângela Matarazzo Fanfa. O caso Samarco: vitimização ambiental e dano social corporativo no cenário de Mariana - uma investigação empírica a partir da perspectiva das vítimas (PARTE II). Revista Eletrônica Direito e Política, Programa de Pós-Graduação Stricto Sensu em Ciência Jurídica da UNIVALI, Itajaí, v.13, n.3, 30 quadrimestre de 2018. Disponível em: www.univali.br/direitoepolitica - ISSN 1980-7791

economia mineira. Os governos, as ONGs, os projetos ambientais e até instituições culturais $^{6}$ se mantêm com dinheiro de empresas do setor da mineração. Só do quadrilátero ferrífero saiu quase $50 \%$ do minério de ferro exportado pelo Brasil em $2015^{7}$.

Quando falo no rompimento da barragem de Fundão como um "desastre rastejante", considero a explicação de Christopher Williams ${ }^{8}$ de que nossa mente está sintonizada em perigos imediatos, como o fogo, por exemplo. Não percebemos prontamente ameaças como a radiação solar ultravioleta. Certamente não desconsidero os alertas empreendidos diante da ameaça do aquecimento global e das mudanças climáticas, mas ocorre que as pessoas estão mais preocupadas em serem vítimas da violência de rua do que com a qualidade do ar que respiram. Da mesma forma, não era objeto de minha investigação saber se a maioria das pessoas em Mariana provavelmente entendia pelo menos o básico da nocividade da mineração, mas esse nível de consciência faria a diferença na resposta a uma exploração que é quadricentenária? Por isso argumentei na primeira parte deste estudo que os danos causados ao meio ambiente adquirem uma naturalidade que se incorpora à vida cotidiana de modo tão normal que é difícil desafiálos.

Eileen Skinnider ${ }^{9}$ toca num ponto importante quando denuncia a falta de inclusão das vítimas ambientais nas pesquisas em vitimologia, e a falta de estudo aprofundado para melhor compreensão da vitimização ambiental. Atribui a invisibilidade das vítimas ambientais também à ausência de reconhecimento como vítimas de "crime", pois muitas práticas ambientalmente nocivas são aprovadas e promovidas pelo Estado; e o fato de que alguns pesquisadores do campo estejam a serviço de governos que desejam obter capital político das vítimas. Esse sentimento assume uma dimensão adicional no que diz com danos ambientais, porque tal discussão também envolve danos perpetrados ou endossados pelo próprio Estado.

marcas da mineração do ferro. Todavia, admite os benefícios socioeconômicos que a mineração proporciona para a população da região, como a geração de emprego e receitas para os municípios.

6 Desde 2012 a Vale S/A patrocina o Instituto Inhotim, um dos mais importantes centros de arte contemporânea do mundo.

7 FERRAZ, Lucas; PRADO, Avener. O caminho da lama. Folha de São Paulo, São Paulo, 2 dez. 2015.

8 WILLIAMS, Christopher. Doing International Research: Global and Local Methods. London: Sage Publications Ltd, 2015.

9 SKINNIDER, Eileen. Victims of Environmental Crime - Mapping the Issues. Vancouver: International Centre for Criminal Law Reform and Criminal Justice Policy, 2011. 
COLOGNESE, Mariângela Matarazzo Fanfa. O caso Samarco: vitimização ambiental e dano social corporativo no cenário de Mariana - uma investigação empírica a partir da perspectiva das vítimas (PARTE II). Revista Eletrônica Direito e Política, Programa de Pós-Graduação Stricto Sensu em Ciência Jurídica da UNIVALI, Itajaí, v.13, n.3, $3^{\circ}$ quadrimestre de 2018. Disponível em: www.univali.br/direitoepolitica - ISSN 1980-7791

Diante dessa argumentação, considera-se a importância econômica da Samarco para os habitantes de Mariana, o que revela que o interesse público sofre de um conflito aparentemente insolúvel e irreconciliável entre a dependência econômica da mineradora e a liberdade, e a mineração e sociedade/meio ambiente. Do exame e análise dos depoimentos, emergem as reações e os sentimentos daqueles que sofrem os efeitos desse conflito e a percepção pessoal que tem de sua relação com o desenvolvimento econômico, o meio ambiente e a degradação ambiental.

Verte dessas narrações uma dinâmica complexa. Por isso, para analisar a conduta omissiva do Estado diante da tragédia do Rio Doce, criei duas categorias que observam os seguintes padrões de acordo com as narrativas das pessoas participantes: a) a ausência de vigilância e de diagnóstico; b) a dependência econômica da mineradora/mineração. No capítulo final, analiso a dimensão dos danos sociais e os aspectos da vitimização ambiental.

\subsection{A AUSÊNCIA DE VIGILÂNCIA E DE DIAGNÓSTICO: A OMISSÃo DO ESTADO}

A omissão do Estado é perceptível em vários pontos dos relatos das vítimas, que confiavam na sua vigilância, presença e assistência antes e após a ruptura da barragem de Fundão. Por isso, percebe-se a prevalência dos interesses econômicos e a negligência do dever de zelar pelo interesse público.

Domingos de Abreu Vieira tem 71 anos, é aposentado, artesão, nasceu e trabalhou em Mariana toda a sua vida. Acredita que onde existe barragem deveria ter um movimento de esclarecimento, de trabalho para vigiar essas atividades ou para vigiar o poder público, para que este fiscalize melhor e eventos como o que ocorreu sejam evitados. E acrescenta que isso se justifica porque a mineração é uma atividade necessária.

As vítimas acreditam que o Estado tem sua parcela de responsabilidade, porque foi omisso na fiscalização. Se de fato ela ocorreu não foi suficiente, foi ineficaz, porque não evitou o romprimento da barragem. Também não havia plano de prevenção, não houve treinamento para situações de emergência, conforme afirmaram as vítimas. Nunca houve sequer uma informação a respeito de como as pessoas deveriam agir. Muitos entrevistados e entrevistadas contam que agora tem sirene nos distritos abandonados de Bento Rodrigues e Paracatu de Baixo.

A negligência nos procedimentos de emergência quando do rompimento da barragem aparecem em todas as narrativas. Não houve aviso, não houve socorro a quem estava impossibilitado de se deslocar. Conforme relatado, nenhum representante do governo do 
COLOGNESE, Mariângela Matarazzo Fanfa. O caso Samarco: vitimização ambiental e dano social corporativo no cenário de Mariana - uma investigação empírica a partir da perspectiva das vítimas (PARTE II). Revista Eletrônica Direito e Política, Programa de Pós-Graduação Stricto Sensu em Ciência Jurídica da UNIVALI, Itajaí, v.13, n.3, $3^{\circ}$ quadrimestre de 2018. Disponível em: www.univali.br/direitoepolitica - ISSN 1980-7791

Estado esteve em Mariana para dar auxílio ou orientação às vítimas. Estas referiram que quando havia cobertura da imprensa estavam todos presentes, ao passo que "hoje é nós contra nós mesmo e a Samarco leva essa quantidade de advogado e a gente não tem lá um representante da Prefeitura com a gente".

Sampaio ${ }^{10}$ aponta para deficiências no plano de ação emergencial ${ }^{11}$ das barragens no Brasil e alerta que embora a legislação brasileira esteja em sintonia com os parâmetros internacionais, no tocante ao conteúdo do Plano de Ação Emergencial é falha, porque não prescreve mecanismos adequados de controle do seu conteúdo. Em razão disso, as ações a serem executadas em "caso de situação de emergência, como procedimentos preventivos e corretivos, além dos meios de divulgação e alerta às comunidades potencialmente atingidas"12, também podem ser falhos.

Os relatos das vítimas demonstraram a falha com relação a todo o procedimento de contingência e de emergência ${ }^{13}$. Na questão das barragens, em particular, o principal papel da Defesa Civil deveria ser o de fazer com que o empreendedor discutisse soluções com os outros órgãos na elaboração de um plano de emergência, bem como que essas ações assegurassem as comunidades atingidas por um acontecimento como o de Fundão.

A atuação da Defesa Civil de Mariana é criticada. Bárbara Eliodora da Silveira recordou que não havia ninguém da Defesa Civil para organizar a evacuação na oportunidade. Carlos narrou que após a devastação pela lama, quem não foi para a arena de Mariana passou a noite ao relento. Não havia abrigo. Lembra que a Defesa Civil só chegou depois que aconteceu tudo. As vítimas estranham o fato de a Defesa Civil fazer um treinamento após todo o ocorrido para preparar a comunidade para o período das chuvas. Não conseguem entender a razão de se fazer isso só após o rompimento da barragem. Outras censuram a Defesa Civil de Mariana e apontam que o órgão praticamente trabalha para a Samarco.

10 SAMPAIO, José Adércio Leite. As deficiências do plano de ação emergencial das barragens no Brasil. Revista Brasileira de Direito, v.12, n. 2, pp. 7-17, jul./dez., 2016.

11 O Plano de Ação Emergencial (PAE) é instrumento da Política Nacional de Segurança de Barragem, instituída pela Lei no $12.334 / 2010$, e requer, dentre várias outras exigências, que o empreendedor elabore um Plano de Ação de Emergência em casos de acidentes em barragens.

12 SAMPAIO, José Adércio Leite. As deficiências do plano de ação emergencial das barragens no Brasil. Revista Brasileira de Direito, v.12, n. 2, pp. 7-17, jul./dez., 2016. p. 10.

${ }^{13}$ A Política Nacional de Proteção e Defesa Civil - PNPDEC, instituída pela Lei no 12.608 de 10 de abril de 2012, traz os princípios, os objetivos e os instrumentos de como serão implementados no Brasil a gestão de riscos de desastres e a gestão de desastres, com o objetivo de "assegurar condições sociais, econômicas e ambientais adequadas para garantir a dignidade da população e garantir a promoção do desenvolvimento sustentável". 
COLOGNESE, Mariângela Matarazzo Fanfa. O caso Samarco: vitimização ambiental e dano social corporativo no cenário de Mariana - uma investigação empírica a partir da perspectiva das vítimas (PARTE II). Revista Eletrônica Direito e Política, Programa de Pós-Graduação Stricto Sensu em Ciência Jurídica da UNIVALI, Itajaí, v.13, n.3, $3^{\circ}$ quadrimestre de 2018. Disponível em: www.univali.br/direitoepolitica - ISSN 1980-7791

O acesso aos subdistritos afetados está proibido por questões de segurança. No entanto, é a Samarco que está guardando o acesso a Bento Rodrigues com cercas e portões enormes e só é permitida entrada com autorização escrita da Defesa Civil. "Nós que somos proprietário não temos acesso a Bento. A estrada é pública, mas tem uma portaria da empresa. Por que a Defesa Civil dá esse tipo de liberdade pra empresa colocar uma portaria com segurança dela?", questiona um dos entrevistados.

Este fato eu pude comprovar quando fui autorizada a visitar Bento Rodrigues somente um dia antes de meu retorno para o Rio Grande do Sul. A Defesa Civil respondia aos meus contatos com evasivas e nada fez até que eu fosse pessoalmente solicitar autorização para visitar o subdistrito. Uma funcionária foi designada para me acompanhar e o transporte que me levou até o local não era da administração pública ou da Defesa Civil. Era da Samarco, com uma motorista da empresa, conforme constatei em seu crachá de identificação.

As vítimas denunciam que conseguem visitar o local quando acompanham a imprensa. A restrição do acesso dos moradores foi tema da audiência pública realizada em abril de 2016 pelo Conselho Municipal do Patrimônio Cultural de Mariana. O prefeito de Mariana, Duarte Júnior, naquela oportunidade afirmou que faria uma reunião com representantes do Ministério Público e da empresa Samarco para buscar uma solução ${ }^{14}$. Todavia, estive em Mariana no mês de outubro de 2016 e a situação permanecia a mesma.

Além de se omitir diante desse fato, o poder público não garante a segurança das áreas atingidas. As residências foram saqueadas. Depois do saque às casas destruídas e também às que ficaram de pé na parte mais alta do distrito, o que restou do patrimônio cultural arrasado pela lama também foi alvo dos saqueadores. O Ministério Público de Minas Gerais denunciou a tentativa de invasão a Igreja de Nossa Senhora das Mercês, do século XVIII, que por ficar na parte mais alta de Bento Rodrigues, escapou da onda de lama. O titular da Coordenadoria das Promotorias de Justiça de Defesa do Patrimônio Cultural e Turístico de Minas Gerais, Marcos Paulo de Souza Miranda, informou que a mineradora Samarco não está cumprindo o acordo de proteger a área ${ }^{15}$.

A omissão também é apontada em relação às obras de melhorias nos subdistritos, deixando espaço para que a empresa realizasse trabalhos que eram de responsabilidade

\footnotetext{
14 COUTO, Douglas. Conselho do Patrimônio define pelo tombamento de Bento e Paracatu. 2016.

15 COORDENADORIA DAS PROMOTORIAS DE JUSTIÇA DE DEFESA DO PATRIMÔNIO CULTURAL E TURÍSTICO DE MINAS GERAIS - CPPC/MPMG. MPMG firma Termo de Compromisso com a Samarco para proteger e evitar maiores danos aos bens culturais remanescentes em distritos de Mariana. 2015.
} 
COLOGNESE, Mariângela Matarazzo Fanfa. O caso Samarco: vitimização ambiental e dano social corporativo no cenário de Mariana - uma investigação empírica a partir da perspectiva das vítimas (PARTE II). Revista Eletrônica Direito e Política, Programa de Pós-Graduação Stricto Sensu em Ciência Jurídica da UNIVALI, Itajaí, v.13, n.3, $3^{\circ}$ quadrimestre de 2018. Disponível em: www.univali.br/direitoepolitica - ISSN 1980-7791

do poder público. Joaquim julga que a dependência da mineração fez com que o poder público deixasse a empresa dominar os distritos. A empresa fazia obras que eram de responsabilidade do poder público, a exemplo de uma caixa d'água instalada em Bento Rodrigues e de outra que estava em construção.

A Samarco também estava coordenando um projeto de produção de pimenta biquinho na comunidade. Joaquim narrou, ainda, que a empresa já tinha disponível um recurso de 14 ou 16 milhões para a construção do asfalto na estrada de acesso ao distrito. "Não dá pra entender uma empresa privada ter que cuidar da saúde, ter que cuidar de água, ter que cuidar de educação. Isso é dever do poder público, a empresa tem que pagar os impostos e o poder público usar eles de maneira correta pra que essas situações sejam solucionadas e aqui em Mariana acontece o contrário".

Outros relatos dão conta de que a Samarco fazia reuniões em Bento Rodrigues para propor a construção de uma área de lazer para as crianças, uma pista para caminhadas etc. Por um período de quatro anos a empresa fez festa do Dia das Crianças no distrito. A população acreditava que a Samarco faria essas melhorias, no entanto, o que acabou sendo feito foi a barragem de Fundão e o discurso mudou para o de que "Bento era lugar de explorar minério, que Bento era rico em minério, que Bento Rodrigues era um distrito muito rico, que a gente tava no meio de riquezas, mas nunca falava que a barragem tava dando problema".

Assim, verifica-se que a disposição da empresa em promover melhorias no distrito, comprar propriedades no entorno da comunidade e realizar estudos sobre a população do distrito, demonstra, implicitamente, o interesse em ampliar as barragens na região. Conforme o plano de lavra vigente, a barragem de Fundão, implantada em 2008, tem uma vida útil de 30 anos $^{16}$. Com as barragens de Fundão, Germano e Santarém com suas capacidades máximas, a mineradora precisaria de um novo depósito de rejeitos. Infelizmente, o rompimento da barragem de Fundão é um grande negócio para a mineradora, pois descartou um volume gigantesco de rejeitos e possibilitou a construção do dique S4 sem a necessidade de comprar o distrito de Bento Rodrigues.

Atenta-se para o fato de que uma das competências do poder executivo é exercer atos que se direcionam ao cumprimento da função administrativa. Toda a atividade administrativa visa à consecução da finalidade do Estado, que é satisfazer o interesse social e cumprir suas obrigações fundamentais de Estado. De acordo com a doutrina de

16 SISTEMA INTEGRADO DE INFORMAÇÃO AMBIENTAL - SIAM, MG. RADA: Relatório de Avaliação do Desempenho Ambiental. 2013. 
COLOGNESE, Mariângela Matarazzo Fanfa. O caso Samarco: vitimização ambiental e dano social corporativo no cenário de Mariana - uma investigação empírica a partir da perspectiva das vítimas (PARTE II). Revista Eletrônica Direito e Política, Programa de Pós-Graduação Stricto Sensu em Ciência Jurídica da UNIVALI, Itajaí, v.13, n.3, $3^{\circ}$ quadrimestre de 2018. Disponível em: www.univali.br/direitoepolitica - ISSN 1980-7791

Hely Lopes Meirelles ${ }^{17}$, os fins da administração se consubstanciam na defesa do interesse público e a obra pública é um fato administrativo, e, como tal, sujeito às regras específicas da Administração.

Essa omissão se agravou com a assinatura do decreto autorizando a construção do dique S4, que vai inundar parte de Bento Rodrigues. Para Cláudio Manuel da Costa, o fato do Estado baixar um decreto desse tipo é tão grave quanto ser omisso na fiscalização. "É apagar a cena de um crime". Para Joaquim José da Silva Xavier, diante de tudo o que aconteceu, "a Samarco ganhou a única coisa que ela sempre quis: o território do Bento".

Com relação à assistência às vítimas, é relevante sublinhar que a Samarco contratou pessoas para trabalhar nos Centros de Referência de Assistência Social (CRAS) e nas escolas. Para as vítimas, é uma forma da empresa manipular a situação com a anuência do poder público. Elas avaliam que o governo dá mais guarida para a empresa sair impune e o ocorrido cair no esquecimento do que cumprir seu papel que é de proteger e punir. Para as vítimas, o Estado preserva somente os interesses da empresa.

Há relatos de que o apoio psicológico e de saúde está sendo custeado pela própria Samarco. "Nessa questão da assistência psicológica a Samarco passa um dinheiro para a prefeitura e a prefeitura contrata os funcionários que, é psicólogo e assistente social". O Estado não presta qualquer assistência. Joaquina foi arrastada pela lama e sobreviveu. Perdeu um filho e a sobrinha. Ela dispensou o atendimento psicológico porque não confia no profissional designado pela Samarco. "Eles chegam na casa da gente pedindo pra gente esquecer daquilo. Como? Me diz pra recomeçar. [...] Como você esquece isso?".

Desse modo, o ato de omissão do Estado, inescusável em todo o contexto que envolve a tragédia do Rio Doce, significa a ausência de vigilância, de diagnóstico, mas acima de tudo representa, para as vítimas, o abandono. Revela-se a ineficácia do Estado de administrar os problemas gerados pelas atividades ambientalmente nocivas, seja porque não tem capacidade para fiscalizar quando as regulamenta, seja porque ao impor uma regulamentação mais dura pode causar a evasão de forças produtivas.

Quanto à ausência de vigilância e de diagnóstico, sobressai a despreocupação com as vidas, a proteção e a prevenção ambiental, ao passo que todos os esforços são direcionados visando o desenvolvimento econômico. O abandono evidencia-se, ainda, nos

\footnotetext{
17 MEIRELLES, Hely Lopes. Direito administrativo brasileiro. 11. ed. São Paulo: Revista dos Tribunais, 1985.
} 
COLOGNESE, Mariângela Matarazzo Fanfa. O caso Samarco: vitimização ambiental e dano social corporativo no cenário de Mariana - uma investigação empírica a partir da perspectiva das vítimas (PARTE II). Revista Eletrônica Direito e Política, Programa de Pós-Graduação Stricto Sensu em Ciência Jurídica da UNIVALI, Itajaí, v.13, n.3, 30 quadrimestre de 2018. Disponível em: www.univali.br/direitoepolitica - ISSN 1980-7791

relatos de que o poder público não está mais presente nas negociações, pois o esforço político é no sentido de reaver as perdas econômicas com a paralisação das atividades da mineradora e por isso o poder público sempre se posiciona a favor desta. $O$ fato de que o atendimento é subsidiado pela Samarco e que todo o processo de cadastramento obedece aos critérios estabelecidos pela própria empresa reforça não só a sensação de abandono, mas de medo e de desconfiança.

Por fim, para reforçar o sentimento de abandono pelo poder público, o decreto autorizando a construção do dique S4 e o alagamento de parte de Bento Rodrigues significa para as vítimas a cumplicidade do Estado para entregar o território de Beto Rodrigues para a mineradora definitivamente, impondo às vítimas a perda de sentido de existência individual e coletiva, e de pertencimento a um lugar (antropologicamente) e a um território (institucionalmente).

Portanto, a conduta do Estado impõe o custo social e ambiental pela exploração de recursos naturais e pelos interesses preponderantemente econômicos. Representa, da mesma forma, a injustiça ambiental, em evidente abandono das vítimas e desvalorização destas em decorrência de atos (ou omissões) cometidos por interesse daqueles que nunca partilharão os riscos e as consequências.

Mesmo diante de todo esse contexto, verifico que o próprio interesse público é contraditório, o que é analisado a seguir.

\subsection{CONFLITO ENTRE A DEPENDÊNCIA ECONÔMICA DA MINERADORA E A LIBERDADE, E A MINERAÇÃO E A SOCIEDADE/MEIO AMBIENTE: ESTADOS DE NEGAÇÃO}

O conceito de "liberdade" não diz apenas com a capacidade que as vítimas da Samarco, Vale e BHP tinham de fazer o que queriam e o que tinham o poder de fazer, como ter a posse e o domínio dos seus bens, ir e vir das suas propriedades, tomar banho nos córregos e cachoeiras, criar animais e plantar alimentos, desfrutar de um meio ambiente saudável, ter acesso a recursos culturais, intelectuais e de informação. É importante acentuar que a liberdade, filosoficamente compreendida, denota a ausência de submissão e de servidão.

John Stuart Mill, em sua obra On Liberty ${ }^{18}$, foi o primeiro a reconhecer a diferença entre liberdade como liberdade de agir e liberdade como ausência de coerção. Considerando

\footnotetext{
18 MILL, John Stuart. On Liberty. 4. ed. Londres: Longman, Roberts, \& Green Co., 1859.
} 
COLOGNESE, Mariângela Matarazzo Fanfa. O caso Samarco: vitimização ambiental e dano social corporativo no cenário de Mariana - uma investigação empírica a partir da perspectiva das vítimas (PARTE II). Revista Eletrônica Direito e Política, Programa de Pós-Graduação Stricto Sensu em Ciência Jurídica da UNIVALI, Itajaí, v.13, n.3, $3^{\circ}$ quadrimestre de 2018. Disponível em: www.univali.br/direitoepolitica - ISSN 1980-7791

que a liberdade diz respeito à ausência de restrições arbitrárias e tem em conta os direitos de todos os envolvidos, como tal, o exercício da liberdade foi limitado pela perda financeira e diminuição substancial de direitos fundamentais.

A palavra "liberdade" é a mais recorrente em todas as entrevistas (15 ocorrências em 12 depoimentos). As frases mais frequentes nas falas dos entrevistados em relação a esta afirmação estão em conformidade com os seguintes padrões: 1) eu preferia ter a liberdade que tinha; 2) a gente tinha liberdade; 3) a liberdade é outra; 4) a gente perdeu aquela liberdade; 5) sem liberdade.

A Samarco controla o cenário da ofensa ambiental, criou os critérios do atingido, que requisitos ele deve preencher para ser assim considerado, e o que ele tem ou não direito. Faz o seu trabalho para controlar tudo através dos atos da Fundação Renova, constituída e administrada pela própria empresa para restaurar e restabelecer as comunidades e os recursos impactados pelo rompimento. A fundação é a grande estratégia de marketing e tentativa de desresponsabilização das acionistas. Isso porque todas as demandas e pautas são dirigidas e solvidas por tal fundação, a exemplo das indenizações, do cartão de auxílio, a porcentagem de $20 \%$ para cada dependente, a cesta básica e o aluguel da moradia.

A vida era totalmente independente da empresa, pois os habitantes dos subdistritos, em sua maioria, desempenhavam atividades autônomas, sem relação de emprego com a Samarco. Na atual situação, o valor auferido pelo auxílio dispendido pela empresa não representa a realidade que as pessoas entrevistadas viviam em Bento Rodrigues e em Paracatu de Baixo, com custo de vida muito inferior ao da cidade. No entanto, a dependência não é apenas desse assistencialismo criado pela fundação Renova após a ruptura da barragem.

A história da mineração é maior do que a história de Fundão. A exploração histórica demonstra que os danos provocados seguiram seu percurso desde o ouro até o minério de ferro. O ciclo do ouro entrou em declínio no final do século XVIII. Até meados do século $\mathrm{XX}$, as atividades de mineração praticamente cessaram. A descoberta de jazidas de pirita, alumínio, manganês e ferro despertou novamente a cobiça, sobretudo de empresas estrangeiras, que investem para explorar ampla e completamente esses minérios ${ }^{19}$. A tragédia do Rio Doce já se anunciava.

19 TAVARES, Ruzimar Batista. Atividades extrativas minerais e seus corolários na bacia do alto ribeirão do Carmo: da descoberta do ouro aos dias atuais. Ouro Preto: UFOP, 2006. 
COLOGNESE, Mariângela Matarazzo Fanfa. O caso Samarco: vitimização ambiental e dano social corporativo no cenário de Mariana - uma investigação empírica a partir da perspectiva das vítimas (PARTE II). Revista Eletrônica Direito e Política, Programa de Pós-Graduação Stricto Sensu em Ciência Jurídica da UNIVALI, Itajaí, v.13, n.3, $3^{\circ}$ quadrimestre de 2018. Disponível em: www.univali.br/direitoepolitica - ISSN 1980-7791

Os grandes interesses sociais e econômicos em jogo nada mais significam para as vítimas do que um grande conflito, como se observa nos seguintes padrões recorrentes nas suas narrativas: 1) "eu acho que a empresa deve voltar a operar, sim, desde que", 2) "eu escuto falar que a lama é contaminada, mas", 3) "atividade necessária", e 4) "nós, os atingidos".

Em relação a todos os padrões vislumbram-se elementos de negação ${ }^{20}$. As fortes evidências desses elementos dizem respeito às vítimas, ao Estado e aos perpetradores ${ }^{21}$.

Os estados de negação constam na obra Stanley Cohen (1942-2013), sociólogo consagrado no campo da criminologia crítica, ao analisar as respostas sociais à desumanidade e às violações de direitos humanos. A negação de responsabilidade inevitavelmente segue um dos quatro caminhos: obediência aos superiores, conformidade com a sociedade, a necessidade ou a divisão da personalidade. Cohen ${ }^{22}$ cita as afirmações de Hannah Arendt de que a falsidade do caráter de Eichmann era parte integrante de toda a sociedade alemã, protegendo-a da realidade. Da mesma forma, o massacre de My Lai, em 1968, no Vietnã, foi, para a facilidade das consciências americanas, definido como um crime de obediência ${ }^{23}$. Dessa maneira, responsabilidade individual e moralidade são minimizadas.

Após o rompimento da barragem, as vítimas ficaram muito mais cientes dos danos causados pela mineração, mas os seus depoimentos revelam a necessidade de conviver com a exploração do minério de ferro. Desse modo, "de acordo com Cohen, a negação envolve um paradoxo fundamental: a fim de negar algo, é necessário, em algum nível, reconhecer sua existência e suas implicações morais" ${ }^{\prime 24}$. Isso se explica por vários

20 A negação, de acordo com Cohen é um mecanismo de defesa do inconsciente para lidar com a culpa, a ansiedade e outras emoções perturbadoras despertadas pela realidade. A psique bloqueia a informação que é literalmente impensável ou insuportável e estabelece uma barreira que impede que o pensamento chegue ao conhecimento consciente.

21 Nos estudos de Natali em Huelva (2014), surgiram várias explicações para justificar a inércia dos habitantes da cidade diante da poluição causada pela indústria química. São os elementos de negação. O fato de estarem habituados com a situação amenizava a realidade do sofrimento fazendo com que as vítimas ambientais se familiarizassem e se adaptassem a essa realidade. Por isso ela tornara-se mais aceitável e menos detectável. Também o tempo da contaminação (desde a década de 1960) fez com que o fenômeno da poluição se expandisse no horizonte, o que contribuiu para que a percepção de risco se dissipasse, gerando dúvida e incerteza quanto a ela. Os discursos públicos dos que ostentavam o impunham e neutralizavam uma certa realidade, causando a inação dos atores sociais na busca de possíveis soluções.

${ }^{22}$ COHEN, Stanley. States of Denial: Knowing about Atrocities and Suffering. Cambridge, UK: Polity Press, 2001. p. 40. (Tradução nossa)

${ }^{23}$ COHEN, Stanley. States of Denial: Knowing about Atrocities and Suffering. Cambridge, UK: Polity Press, 2001. p. 43. (Tradução nossa)

${ }^{24}$ MARSHALL, George. A psicologia da negação. In: DREYER, Lilian. Augusto Carneiro: depois de tudo um ecologista. Buqui Livros Digitais, 2014. p. 134. 
COLOGNESE, Mariângela Matarazzo Fanfa. O caso Samarco: vitimização ambiental e dano social corporativo no cenário de Mariana - uma investigação empírica a partir da perspectiva das vítimas (PARTE II). Revista Eletrônica Direito e Política, Programa de Pós-Graduação Stricto Sensu em Ciência Jurídica da UNIVALI, Itajaí, v.13, n.3, $3^{\circ}$ quadrimestre de 2018. Disponível em: www.univali.br/direitoepolitica - ISSN 1980-7791

motivos, entre os quais a falta de alternativas à mineração, embora existam mecanismos para construir tais alternativas, como por exemplo, o potencial turístico da região. 0 problema, pois, não radica em torno da invisibilidade da atividade da empresa. A mineração é visível e sistemática há séculos, e é precisamente essa repetição que representa a proteção contra a maioria das suas implicações. Logo, é possível verificar que alguns dos fatos não são negado per se, mas a interpretação é tal que a dimensão das implicações é que é negada. Por isso, entendo que a extensão da vitimização nessa esfera carece de estudos aprofundados sobre os efeitos da negação no bem-estar psicossocial das vítimas ambientais. Tais estudos podem (ainda que não concentrados no negacionismo porque cada grupo é afetado de maneiras distintas) contribuir para a investigação do sofrimento psíquico nos níveis intragrupo e intergrupo ${ }^{25}$.

Para George Marshall26, a descrição de Cohen se encaixa muito bem com as atuais respostas da sociedade ao problema das mudanças climáticas e no caso analisado, se encaixaria perfeitamente quanto às implicações da mineraç̧ão. O autor nota como o conhecimento do problema está estabelecido na sociedade, mas claramente esta se recusa a reconhecer suas implicações. Vale-se da teoria de Cohen para explicar alguns processos psicológicos pertinentes às questões ambientais, especialmente as mudanças climáticas.

[...] pode-se esperar uma negação generalizada quando a dimensão e a natureza do problema são sem precedentes, de forma que as pessoas não têm mecanismos culturais para aceitálas. No caso das mudanças climáticas, então, podemos aceitar a evidência de que elas estão ocorrendo, mas achamos extremamente árduo aceitar nossa responsabilidade por um crime de tamanha grandeza ${ }^{27}$.

A evidência mais forte da negação, segundo Marshall, é a falha de reconhecer a existência da dimensão moral em que se podem identificar vítimas e culpados. Depois,

${ }^{25}$ A questão do sofrimento psíquico é profundamente estudada no Projeto Refugiados de Belo Monte, um projeto de crowdfunding que tem a frente a jornalista Eliane Brum, o psicanalista e professor titular do Instituto de Psicologia da USP, Christian Dunker, e a psicanalista Ilana Katz. Uma pequena equipe de profissionais da área de saúde mental testou o modelo de intervenção chamado de Clínica de Cuidado, em julho de 2016, na região de Altamira. Em janeiro de 2017, um grupo maior, formado por 15 profissionais, realizou uma primeira intervenção na região, por um período de 15 dias, todos de forma voluntária. O objetivo é "construir um modelo de intervenção em saúde mental junto à população ribeirinha atingida por Belo Monte, um dispositivo de atenção ao sofrimento psíquico para atender aqueles que, em curto espaço de tempo, perderam as referências fundamentais de organização e funcionamento da própria vida". Esses relatos serão transformados em um documentário público. Informações sobre o projeto no website www.catarse.me/refugiadosdebelomonte.

${ }^{26}$ MARSHALL, George. A psicologia da negação. In: DREYER, Lilian. Augusto Carneiro: depois de tudo um ecologista. Buqui Livros Digitais, 2014.

27 MARSHALL, George. A psicologia da negação. In: DREYER, Lilian. Augusto Carneiro: depois de tudo um ecologista. Buqui Livros Digitais, 2014. p. 134. 
COLOGNESE, Mariângela Matarazzo Fanfa. O caso Samarco: vitimização ambiental e dano social corporativo no cenário de Mariana - uma investigação empírica a partir da perspectiva das vítimas (PARTE II). Revista Eletrônica Direito e Política, Programa de Pós-Graduação Stricto Sensu em Ciência Jurídica da UNIVALI, Itajaí, v.13, n.3, $3^{\circ}$ quadrimestre de 2018. Disponível em: www.univali.br/direitoepolitica - ISSN 1980-7791

quando esperamos que outro alguém intervenha e tome uma atitude, estamos tornando nossa responsabilidade difusa.

Cohen escreve longamente sobre o "efeito do observador passivo", quando crimes violentos são cometidos em uma rua repleta de pessoas sem que ninguém intervenha. Os indivíduos esperam que outro alguém tome uma atitude, diluem sua responsabilidade pessoal na responsabilidade coletiva. Uma característica curiosa do efeito do observador passivo é que, quanto maior o número de atores, menor a probabilidade de que alguma pessoa se sinta capaz de tomar uma atitude. No caso das mudanças climáticas, somos ao mesmo tempo observadores e algozes, um conflito interno que só intensifica a negação ${ }^{28}$.

Para Cohen ${ }^{29}$, toda a atrocidade constrói uma relação triangular: a vítima (contra quem as coisas são feitas), o perpetrador (quem faz as coisas) e os espectadores (aqueles que veem e sabem o que está acontecendo). Esses papéis não são fixos, eles podem sobrepor-se.

Todos nós somos espectadores externos, pois acompanhamos as imagens, os textos sobre Fundão através da imprensa. A mídia apelou para a ação dos espectadores: as doações e o voluntariado ocorreram e foram essenciais para a minimização do sofrimento. Interpreto que as ações dos movimentos sociais na organização e assistência às vítimas são também formas de pedido de ação dos observadores. Noto, entretanto, que retornam às mesmas questões que impediram vítimas e movimentos sociais de reagir preventivamente ao rompimento da barragem de Fundão: a importância econômica da empresa e o agravamento da situação com a paralização das atividades (negação de conformidade com a necessidade).

Luís Vaz de Toledo Pisa, participante da pesquisa, se posiciona a favor da volta das operações da mineradora. Para ele, não importa quem operará a empresa, pois Mariana é completamente dependente da mineração. Enfatiza que não existe um "plano B" se a exploração mineral se extinguir. Para Joaquim José da Silva Xavier, infelizmente a mineração é a opção que a cidade tem, logo, acredita que a empresa deve voltar a operar, mas de forma consciente, "uma mineração com responsabilidade, entendeu? Com investimento em segurança, em estrutura das barragens". Hipólita Jacinta Teixeira de Melo não pensa diferente: "a Samarco deve voltar a operar, sim, desde que consiga o licenciamento adequado, porque ela gera empregos". Carlos Corrêa de Toledo gostaria de

28 MARSHALL, George. A psicologia da negação. In: DREYER, Lilian. Augusto Carneiro: depois de tudo um ecologista. Buqui Livros Digitais, 2014. p. 134. 2001.

${ }^{29}$ COHEN, Stanley. States of Denial: Knowing about Atrocities and Suffering. Cambridge, UK: Polity Press, 
COLOGNESE, Mariângela Matarazzo Fanfa. O caso Samarco: vitimização ambiental e dano social corporativo no cenário de Mariana - uma investigação empírica a partir da perspectiva das vítimas (PARTE II). Revista Eletrônica Direito e Política, Programa de Pós-Graduação Stricto Sensu em Ciência Jurídica da UNIVALI, Itajaí, v.13, n.3, $3^{\circ}$ quadrimestre de 2018. Disponível em: www.univali.br/direitoepolitica - ISSN 1980-7791

ter seu emprego de volta, desde que a empresa opere com responsabilidade. Acredita que a paralização das atividades é tão prejudicial quanto à ruptura da barragem. Preocupa-se com as pessoas, que embora não tenham sido atingidas diretamente pela lama, foram atingidas indiretamente com a perda de seus empregos e não contam com nenhuma assistência da empresa.

Bento Rodrigues foi fundado no século XVIII, um povoado que surgiu da mineração do ouro. No auge da mineração do ouro, a região de Bento, Camargos, Santa Rita do Durão, eram lugares muito movimentados. Depois, com a decadência do ouro no século XIX a população "caiu praticamente no esquecimento como toda a região aqui de Mariana, toda a região dos Inconfidentes. Mariana, Bento ficaram um tempo no esquecimento, meio que congelado no tempo". Depois disso, com o surgimento de uma nova economia baseada no minério de ferro, mais ou menos no final da década de 1970, início da década de 1980, a região volta a ser economicamente forte, com oportunidade de emprego para as pessoas. Francisco ressalta que a exploração do minério de ferro causou um "boom demográfico e econômico". Os royalties que as mineradoras pagam para as prefeituras passaram a ser rica fonte de expansão, oportunizando maior estruturamento das cidades e povoados. Esse fato revela o temor que os habitantes têm de que com o abandono da atividade minerária haja um novo hiato no desenvolvimento das cidades, a exemplo do que ocorreu com a mineração de ouro (negação de conformidade com a sociedade).

Assim, apesar da dimensão do problema, os habitantes não têm mecanismos culturais para aceitá-lo, porque a mineração é ato centenário e seus efeitos são familiares, a população já está habituada a essa realidade. Os danos se perderam no horizonte temporal até que o evento de Fundão rompeu com essa realidade ${ }^{30}$.

O estado de negação das vítimas da Samarco, Vale e BHP faz com que sejam, a um só tempo, vítimas, observadores e perpetradores. Elas narraram que nunca exigiram esclarecimentos sobre a segurança da barragem e a ausência de programas de prevenção e emergência.

Entretanto, de acordo com Padre Rolim, havia preocupação cada vez mais presente, porque existem várias mineradoras no entorno. Havia preocupação com a questão da

\footnotetext{
30 Não posso deixar de referir aqui o papel dos movimentos sociais na mobilização política das vítimas no caso do rompimento da barragem e de uma forma mais abrangente em relação à temática da mineração. $O$ envolvimento do MAB e da Arquidiocese de Mariana não se trata apenas de oposição a uma "classe dirigente" ou de um "recurso de mobilização". Essa atuação está reivindicando mudanças no governo, na empresa, no trabalho, no mercado, no consumo, no meio ambiente e na sociedade.
} 
COLOGNESE, Mariângela Matarazzo Fanfa. O caso Samarco: vitimização ambiental e dano social corporativo no cenário de Mariana - uma investigação empírica a partir da perspectiva das vítimas (PARTE II). Revista Eletrônica Direito e Política, Programa de Pós-Graduação Stricto Sensu em Ciência Jurídica da UNIVALI, Itajaí, v.13, n.3, 30 quadrimestre de 2018. Disponível em: www.univali.br/direitoepolitica - ISSN 1980-7791

mineração há muito tempo, com as crateras, com o dano, tanto que foram realizados seminários sobre questões ambientais e constituídas equipes de meio ambiente nas dioceses. No entanto, seu depoimento manifesta-se contraditório quando se revela um observador imediato: afirma que se a preocupação com a barragem existia, imagina que deveria ser da parte de quem convivia mais próximo com isso. Para o entrevistado, o acontecimento de fato "acendeu esta luz para o que é a barragem, as suas implicações, aí toda a discussão do que é a mineração também".

Por que esses atores sociais não produziram nenhum ativismo capaz de buscar possíveis soluções até que o rompimento da barragem ocorresse e a mineração passasse a ser questionada com mais combatividade? Cohen ${ }^{31}$ argumenta que a qualquer momento podemos justificadamente alegar (isto é, não estamos mentindo) que não podemos e não percebemos tudo o que está acontecendo à nossa volta. "A psicologia cognitiva confirma que as pessoas são bombardeadas com muitos estímulos para a mente processar"32. Portanto, precisamos ser altamente seletivos e um filtro perceptual é colocado sobre a realidade. Nem podemos nos sentir emocionalmente movidos ou obrigados a agir em resposta a tudo o que absorvemos.

Nota-se o estado de negação tanto das vítimas ambientais como dos perpetradores e observadores; a percepção do risco dispersa pela atividade da mineração essencial para a economia; a percepção distorcida do problema influenciada pelos discursos públicos que impõem e neutralizam uma certa realidade; e por fim, o evento de Fundão fez emergir com força do inconsciente a questão da injustiça ambiental e a privação do direito de desfrutar de direitos fundamentais, tais como a liberdade, a moradia, o trabalho digno, a integridade cultural, a vida, o território e o direito de informação.

Quando se trata de mineração, atividade com alto potencial de dano ambiental, a comunidade deve ser envolvida em larga escala nos processos de avaliação de riscos e no diagnóstico após os danos alegados. A participação é importante não só do ponto de vista da legitimidade, mas também pode aumentar a resolução dos problemas ${ }^{33}$. Do ponto de vista da justiça ambiental, a ausência de participação das vítimas de Fundão anteriormente ao evento e após este é conceitualmente evidente porque há grandes 2001.

${ }^{31}$ COHEN, Stanley. States of Denial: Knowing about Atrocities and Suffering. Cambridge, UK: Polity Press,

32 COHEN, Stanley. States of Denial: Knowing about Atrocities and Suffering. Cambridge, UK: Polity Press, 2001. p. 15 (Tradução nossa)

${ }^{33}$ Resource extraction leaves something behind: environmental justice and mining. International Journal for Crime, Justice and Social Democracy, v. 2, n. 1, pp. 50-64, abr., 2013c. 
COLOGNESE, Mariângela Matarazzo Fanfa. O caso Samarco: vitimização ambiental e dano social corporativo no cenário de Mariana - uma investigação empírica a partir da perspectiva das vítimas (PARTE II). Revista Eletrônica Direito e Política, Programa de Pós-Graduação Stricto Sensu em Ciência Jurídica da UNIVALI, Itajaí, v.13, n.3, $3^{\circ}$ quadrimestre de 2018. Disponível em: www.univali.br/direitoepolitica - ISSN 1980-7791

interesses sociais específicos em jogo - governo, empresa, trabalhadores, consumidores, ambientalistas, comunidades ribeirinhas, indígenas e quilombolas. A tendência é de que a participação e deliberação no debate público sejam reduzidas.

A Samarco, como perpetradora, não nega tenha causado o dano. Admite-o publicamente e pede desculpas. Mas justifica sua importância no cenário econômico, na prática de ações para assistir às pessoas atingidas e na reparação dos danos ao meio ambiente, e preocupa-se em voltar a operar assegurando sua viabilidade ambiental.

A negação representa um componente importante do sofrimento social porque as fontes de percepção acerca da transformação destrutiva do meio ambiente pela mineração seguem sendo insuficientemente exploradas. Na verdade, o que existia anteriormente ao rompimento da barragem era uma relação de sujeição da comunidade marianense especialmente no âmbito do sistema de exploração de recursos minerários.

Até que ponto, após a tragédia do Rio Doce, as pessoas foram empurradas para a realidade e se tornaram mais conscientes? A perda da liberdade mudou suas ações alinhando-as ao conhecimento ou continuaram vivendo em negação? Eu responderia que esse conflito não só aumentou a complexidade da relação, mas evidenciou as condições sob as quais a informação é reconhecida e atuada. A liberdade foi o custo para um grupo de pessoas prestar a atenção e despertar para a ação.

Diante desse conflito, fica evidente a complexidade de uma relação que revela a existência de múltiplos grupos de vítimas com interesses concorrentes, impondo uma limitação muito grande à efetiva resolução do problema. Não posso deixar de acentuar que ao evidenciar os elementos de negação tanto das vítimas como da parte socialmente privilegiada (empresa e poder público) não quero estabelecer uma responsabilidade coletiva. Essas constatações são mais um expediente que auxilia na compreensão do fenômeno e um instrumento para superar situações semelhantes.

\section{A DIMENSÃO DOS DANOS SOCIAIS}

A análise dos danos sociais à comunidade marianense e os aspectos da vitimização ambiental revelam a dimensão e as particularidades que revestem o caso Samarco. As vítimas interpretam o que sofreram de maneiras distintas, mas todas sob o ponto de vista de "crime". Entretanto, os danos não são somente resultado de uma vitimização criminal ambiental. A observação sob o ponto de vista de "crime" daqueles que sofrem de suas consequências sociais e ecológicas, é favorável à negação e o iter criminis, como 
COLOGNESE, Mariângela Matarazzo Fanfa. O caso Samarco: vitimização ambiental e dano social corporativo no cenário de Mariana - uma investigação empírica a partir da perspectiva das vítimas (PARTE II). Revista Eletrônica Direito e Política, Programa de Pós-Graduação Stricto Sensu em Ciência Jurídica da UNIVALI, Itajaí, v.13, n.3, $3^{\circ}$ quadrimestre de 2018. Disponível em: www.univali.br/direitoepolitica - ISSN 1980-7791

ressalta Natali ${ }^{34}$, desaparece no tempo e no espaço, apagando os traços da determinação e da volição dos perpetradores.

Por isso, como expliquei na primeira parte do artigo, esta pesquisa trabalha em uma definição ampliada de crime, alcançando a definição de dano social ${ }^{35}$. É dentro da perspectiva de dano social que examino os tipos e dimensões do impacto da degradação ambiental sobre a comunidade marianense.

As formas de danos ou impactos sociais se apresentam como danos à saúde (física e mental), e são imediatamente as mais claras e preocupantes implicações para as vítimas da Samarco, Vale e BHP. Eles são evidentes (ou se tornarão ao longo do tempo). A Samarco não informa os componentes da lama que vazou da barragem. "O último laudo da composição da lama de rejeito das barragens Germano e Fundão, ano de 2014, informa que é composta basicamente por óxido de ferro e sílica"36.

O laudo preliminar do IBAMA indicou a presença de alumínio, bário, cálcio, chumbo, cobalto, cobre, cromo, estanho, ferro, magnésio, manganês, níquel, potássio e sódio ${ }^{37}$. 0 Instituto de Gestão das Águas de Minas Gerais monitora o Rio Doce em doze trechos entre a cidade de Rio Doce e Belo Oriente e constatou alta turbidez e presença de ferro e manganês em níveis acima do recomendado. A água não é recomendada para animais nem para irrigação de plantações. Para abastecimento, só com tratamento. O aumento na quantidade de metais pesados na foz do Rio Doce também foi detectado por pesquisadores da Universidade Federal do Espírito Santo (UFES) em coletas de sedimentos realizadas entre novembro e dezembro de 2016. Os índices de metais, principalmente ferro e alumínio, ficaram próximos àqueles encontrados no mesmo período em 2015.

A Universidade Federal do Rio de Janeiro (UFRJ) e o Greenpeace realizaram um estudo que revelou que, além do Rio Doce, as águas subterrâneas da região estão contaminadas com altos níveis de ferro e manganês, que prejudicam o desenvolvimento das plantações

\footnotetext{
34 NATALI, Lorenzo. Criminology, victimización medioambiental y social harm - El caso de Huelva (España). Revista Crítica Penal y Poder. OSPDH, n. 7, pp. 5-34, set., 2014.

35 Schwendinger e Schwendinger (1988), na coletânea histórica "Criminologia crítica", advertem que enquanto criminólogas e criminólogos não repensarem o conceito de crime, sobretudo para superar sua definição legalista, eles seguirão sendo defensores da ordem, e não guardiães dos direitos humanos.

36 IBAMA. Laudo Técnico Preliminar: Impactos ambientais decorrentes do desastre envolvendo o rompimento da barragem de Fundão, em Mariana, Minas Gerais. 2015. p. 30.

37 IBAMA. Laudo Técnico Preliminar: Impactos ambientais decorrentes do desastre envolvendo o rompimento da barragem de Fundão, em Mariana, Minas Gerais. 2015. p. 32.
} 
COLOGNESE, Mariângela Matarazzo Fanfa. O caso Samarco: vitimização ambiental e dano social corporativo no cenário de Mariana - uma investigação empírica a partir da perspectiva das vítimas (PARTE II). Revista Eletrônica Direito e Política, Programa de Pós-Graduação Stricto Sensu em Ciência Jurídica da UNIVALI, Itajaí, v.13, n.3, $3^{\circ}$ quadrimestre de 2018. Disponível em: www.univali.br/direitoepolitica - ISSN 1980-7791

e oferecem riscos à saúde, no longo prazo ${ }^{38}$. Em Belo Oriente há cinco pontos de coleta com níveis de ferro e manganês acima do estabelecido pelo Conselho Nacional do Meio Ambiente (CONAMA), órgão do Ministério do Meio Ambiente. Em Governador Valadares são doze pontos e em Colatina, dez pontos com os valores que ultrapassam o permitido. O estudo aponta que a água desses locais não é adequada para consumo humano e, em alguns casos, também não é recomendado o uso para irrigação de plantas, a exemplo de alguns pontos de Governador Valadares e Colatina. Quanto aos efeitos, no longo prazo, para a saúde, "a exposição ao manganês pode causar problemas neurológicos, semelhantes ao mal de Parkinson, enquanto o ferro, em quantidades acima das permitidas, pode danificar rins, fígado e o sistema digestivo" ${ }^{\prime \prime}$.

Os dados do relatório do Instituto Saúde e Sustentabilidade em parceria com o Greenpeace, de março de 2017, apontaram a intoxicação por níquel em onze moradores da cidade de Barra Longa, atingida pelo rompimento da barragem da Samarco, em novembro de 2015. Os exames foram realizados em apenas 11 moradores (em razão de falta de recursos da organização) com idades entre 2 e 92 anos e 13 metais foram pesquisados. Todos os participantes apresentaram aumento de níquel no sangue e 10, diminuição de zinco. Três apresentaram pequeno aumento de arsênio e cinco pessoas registraram o nível de arsênio acima da normalidade ${ }^{40}$.

A respeito dos danos à saúde mental, Tomas Antonio Gonzaga reclama que ficou com problemas de memória: "eu pareço normal, mas sinto uma tremenda dificuldade de lembrar das coisa". Luís destaca que alguns trabalhadores têm relatado ansiedade e depressão, e estão sendo encaminhados para tratamento. Também ressaltou que o nível de alcoolismo entre os trabalhadores está altíssimo e que inclusive tem conhecimento de uma tentativa de suicídio. A esposa de Carlos entrou em depressão, assim como muitos de seus conhecidos. O próprio entrevistado revelou que pensou em colidir seu carro com uma carreta na estrada, pois pensou que sua família ficaria melhor ao receber o seguro. Joaquim procurou ajuda psicológica: "nos primeiros três meses eu não dormia. Quando dormia, acordava assustado. Tem hora que eu acordo que eu acho que tô na minha casa". [...] Falar que curou, que essa dor passou, não consegue. A dor não passa".

38 BOHEM, Camila. Além do Rio Doce, águas subterrâneas da bacia também estão contaminadas. EBC Agência Brasil, São Paulo, 15 abr. 2017.

39 BOHEM, Camila. Além do Rio Doce, águas subterrâneas da bacia também estão contaminadas. EBC Agência Brasil, São Paulo, 15 abr. 2017.

40 VORMITTAG, Evangelina da Motta Pacheco Alves de Araujo; OLIVEIRA, Maria Aparecida de; RODRIGUES, Cristina Guimarães; GLERIANO, Josué Souza. Avaliação dos riscos em saúde da população de Barra Longa/MG afetada pelo desastre. Instituto Saúde e Sustentabilidade e Greenpeace, 2017. 
COLOGNESE, Mariângela Matarazzo Fanfa. O caso Samarco: vitimização ambiental e dano social corporativo no cenário de Mariana - uma investigação empírica a partir da perspectiva das vítimas (PARTE II). Revista Eletrônica Direito e Política, Programa de Pós-Graduação Stricto Sensu em Ciência Jurídica da UNIVALI, Itajaí, v.13, n.3, $3^{\circ}$ quadrimestre de 2018. Disponível em: www.univali.br/direitoepolitica - ISSN 1980-7791

Com relação aos danos econômicos, são percebidos tanto a nível coletivo (desemprego, baixa no turismo, crise no comércio, na pesca e na agricultura) como individual (perda dos meios de subsistência e insuficiência financeira diante do custo de vida na cidade). Os habitantes dos subdistritos que tiveram que se mudar para Mariana reclamam que o custo de vida na cidade é muito alto. Alguns faziam silagem, vendiam cavalos e gado de corte. O custo na cidade é mais alto porque não há como plantar os alimentos. Alguns estão retomando devagar essas atividades fazendo horta, comprando galinhas e porcos para criar e consumir.

Os pequenos agricultores são os mais prejudicados, já que não têm outra fonte de água para a produção e para beber. Especialmente na foz do rio Doce, houve praticamente a extinção do turismo local e a pesca continua proibida até hoje ${ }^{41}$. A pesquisa realizada pela Universidade Federal do Rio de Janeiro (UFRJ) e o Greenpeace indentificou que no curto prazo, o grande impacto tem sido na agricultura. O estudo analisou o modo de vida dos produtores locais e de que modo se deu o impactado da lama. "Muitos dos que não abandonaram suas terras enfrentaram dificuldades financeiras por não conseguir mais produzir com o solo e a água que têm"42. O relatório ainda aponta que houve alteração do tipo de cultivo ou criação após o evento de Fundão e que a produção de cabras foi bastante afetada e as atividades de pesca e criação de peixes praticamente desapareceram.

Quantificar os impactos sociais ou culturais como resultado do dano ambiental causado pela ruptura de Fundão é um desafio. A perda de atividades tradicionais, culturais e de um estilo de vida em si tem efeitos significativos. As culturas tradicionais, especialmente para pequenas comunidades rurais, com forte influência religiosa como no caso, fornecem aos indivíduos necessidades práticas da vida. Em razão da destruição do meio ambiente e do patrimônio cultural dessas comunidades (especialmente igrejas com patrimônios centenários), muitas referências se perderam.

As vítimas externam sua preocupação com a inundação de Bento após a construção do dique S4, com o que não concordaram. O valor sentimental, religioso e histórico se perderá e não sabem como terão acesso a isso. "Como fica a memória disso?". A tentativa de manter os laços culturais e sociais é um trabalho que vem sendo feito pelos movimentos sociais. Especialmente os festejos religiosos uniam essas comunidades e foi

\footnotetext{
41 MOVIMENTO DOS ATINGIDOS POR BARRAGENS - MAB. Foz do Rio Doce apresenta quantidade de metais pesados similar ao período do rompimento. 2017.

42 BOHEM, Camila. Além do Rio Doce, águas subterrâneas da bacia também estão contaminadas. EBC Agência Brasil, São Paulo, 15 abr. 2017.
} 
COLOGNESE, Mariângela Matarazzo Fanfa. O caso Samarco: vitimização ambiental e dano social corporativo no cenário de Mariana - uma investigação empírica a partir da perspectiva das vítimas (PARTE II). Revista Eletrônica Direito e Política, Programa de Pós-Graduação Stricto Sensu em Ciência Jurídica da UNIVALI, Itajaí, v.13, n.3, $3^{\circ}$ quadrimestre de 2018. Disponível em: www.univali.br/direitoepolitica - ISSN 1980-7791

possível mantê-los somente em parte. Bárbara teme que o tempo prolongado na cidade faça as pessoas mais jovens mudarem seus hábitos, que não queiram mais voltar para o novo distrito.

Solinís ${ }^{43}$, ao discorrer sobre a territorialização e sua dimensão histórico-cultural, salienta que os objetos, reunidos em um conjunto determinado, podem ser deslocados de um espaço a outro sem perder seu sentido graças à simbolização. Ele usa como exemplo "a paisagem edilícia da Polis Grega" como uma "transposição criativa de significações" onde "os mitos que tinham lugar na natureza e se identificavam com seus elementos foram traduzidos em edifícios análogos transpostos à cidade". Esses edifícios, estruturas artificiais, representavam as qualidades da paisagem natural sagrada e permitiam reunir, em um só lugar, algumas das paisagens associadas às origens mais importantes.

Se o homem/mulher é um "animal territorial", a sua busca de apropriação do espaço, desde o ponto de vista antropológico, tem origens na sua necessidade de marcar e identificar-se com o âmbito onde vive. A família (ampliada) dá sentido ao espaço onde se habita relacionando-o diretamente com a origem do indivíduo, recordando e consagrando o espaço, como morada de seus corpos e almas, aos antecessores. A religião, por sua vez, na sua função vinculante entre seus dois mundos, tem igualmente um papel importante a cumprir na conotação de espaços construídos, como a configuração de trilhas a partir das procissões que marcavam e ungiam o espaço estruturando territórios, ou a consagração de um sítio a um santo padroeiro da igreja, o que convertia tais territórios em lugares. ${ }^{44}$

Assim o espaço de vida se configurava em Bento Rodrigues e Paracatu de Baixo. Seus habitantes estavam enraizados, assim como suas crenças, "fazendo-os suscetíveis de apropriação desde as entranhas de seus grupos, delimitando-se e por sua vez configurando a estrutura, a organização e o funcionamento do grupo social"45.

Em Bento Rodrigues e Paracatu de Baixo houve o rompimento desse vínculo com o soterramento dos povoados e os seus símbolos representados nas edificações históricas que remontavam ao período colonial, nos caminhos da Estrada Real, nos córregos e cachoeiras límpidos, nos bosques e florestas.

43 SOLINÍS, Germán. O que é o território ante o espaço? In: RIBEIRO, Maria Teresa Franco; MILANI, Carlos Roberto Sanchez (Org.). Compreendendo a complexidade socioespacial contemporânea: o território como categoria de diálogo interdisciplinar. Salvador: EDUFBA: 2009. p. 278.

${ }^{44}$ SOLINÍs, Germán. O que é o território ante o espaço? In: RIBEIRO, Maria Teresa Franco; MILANI, Carlos Roberto Sanchez (Org.). Compreendendo a complexidade socioespacial contemporânea: o território como categoria de diálogo interdisciplinar. Salvador: EDUFBA: 2009. p. 277.

${ }^{45}$ SOLINÍs, Germán. O que é o território ante o espaço? In: RIBEIRO, Maria Teresa Franco; MILANI, Carlos Roberto Sanchez (Org.). Compreendendo a complexidade socioespacial contemporânea: o território como categoria de diálogo interdisciplinar. Salvador: EDUFBA: 2009. p. 277. 
COLOGNESE, Mariângela Matarazzo Fanfa. O caso Samarco: vitimização ambiental e dano social corporativo no cenário de Mariana - uma investigação empírica a partir da perspectiva das vítimas (PARTE II). Revista Eletrônica Direito e Política, Programa de Pós-Graduação Stricto Sensu em Ciência Jurídica da UNIVALI, Itajaí, v.13, n.3, $3^{\circ}$ quadrimestre de 2018. Disponível em: www.univali.br/direitoepolitica - ISSN 1980-7791

\section{OS ASPECTOS DA VITIMIZAÇÃO AMBIENTAL}

Como aspectos da vitimização ambiental são verificáveis, em primeiro, a desagregação social e cultural. Este aspecto relaciona-se diretamente com o impacto cultural sofrido pelas vítimas. Os habitantes de Bento Rodrigues e Paracatu de Baixo foram deslocados para Mariana (desterritorialização), onde residem em casas alugadas pela Samarco em vários pontos distintos da cidade. Suas crianças não estudam mais na mesma escola. 0 encontro e o diálogo diário, as festas religiosas, o banho no córrego, as pescarias perderam-se.

De acordo com Williams ${ }^{46}$, mulheres e crianças podem ser marginalizadas, maltratadas e ignoradas. Este estudo revela que as vítimas da Samarco, de forma geral, estão sofrendo preconceito e discriminação. Foram narradas desavenças, agressões verbais, criminalização dos movimentos sociais. Isso tem relação com outro traço, o sentimento de abandono comunitário, aspecto que a arquidiocese tem trabalhado muito para evitar.

As vítimas sentem que a sociedade se revoltou contra elas. Relatam que muitas pessoas pensam que as vítimas estão "nadando no dinheiro", que não precisam de nada porque a Samarco está fazendo tudo por elas. Ao comentar sobre a parte da indenização já recebida, um dos entrevistados confessou que "se não tivesse feito isso pra nós seria melhor. Eu acho que não tinha criado essa revolta". Tomas sofreu muito com o preconceito e seus filhos também, pois na escola em que estudam em Mariana, "não são bem aceito lá não. Até parece que somos invasor".

Algumas pessoas da comunidade de Mariana pensam que as vítimas são culpadas pela paralisação da empresa. Há relatos de xingamentos do tipo "são um bando de vagabundo que fica explorando a Samarco, que a Samarco não volta a funcionar porque os vagabundo tá explorando ela, tá pegando dinheiro dela, querendo coisa demais além do que tem direito". Outras ofensas como "chama de pobre, chama de tudo quanto é coisa. Fala que os atingidos veio pra cá só pra tumultuar a cidade, que os atingidos hoje tá com dinheiro, tá com aluguel, tá com tudo. Agradeça a Samarco".

\footnotetext{
${ }^{46}$ WILLIAMS, Christopher. Environmental victims - new risks, new injustices. New York: Earthscan, 2013.
} 
COLOGNESE, Mariângela Matarazzo Fanfa. O caso Samarco: vitimização ambiental e dano social corporativo no cenário de Mariana - uma investigação empírica a partir da perspectiva das vítimas (PARTE II). Revista Eletrônica Direito e Política, Programa de Pós-Graduação Stricto Sensu em Ciência Jurídica da UNIVALI, Itajaí, v.13, n.3, $3^{\circ}$ quadrimestre de 2018. Disponível em: www.univali.br/direitoepolitica - ISSN 1980-7791

Trata-se, portanto, de segregação socioespacial ou alienação socioespacial, pois se percebe a marginalização desse grupo social no espaço urbano. Ora, rompido o vínculo antropológico e institucional com o território e perdida a identificação com os objetos naturais e artificiais que constituíam o universo das vítimas, interrompeu-se o "processo de reunificação da sua estrutura significante" ${ }^{\prime \prime 7}$. Em consequência, estas perderam seu lugar por um efeito de alienação.

Outro aspecto da vitimização ambiental no caso Samarco é a redução das perspectivas de emprego e o déficit de competências. Luís destaca que a Samarco e a Vale empregam cerca de 10 mil funcionários. A paralisação das atividades da Samarco causou impacto socioeconômico muito forte na região, pois a mineração é responsável por $70 \%$ dos postos de trabalho ${ }^{48}$. Luís crê que a cidade está vivenciando um caos social. Para as vítimas, trabalhar na cidade é quase impossível. As pessoas que viviam no interior não são capacitadas para o mercado de trabalho na cidade. A maioria dos habitantes de Bento e Paracatu exerciam atividades como pedreiros, carpinteiros, agricultores, criadores de animais, produziam leite, grãos, hortaliças etc.

Os dados do Sindicato Metabase apontam uma média de 12 mil desempregados na cidade e acredita-se que o número vai aumentar em razão da suspensão das atividades da Samarco. Com as demissões que ocorreram, em torno de dois mil, as consequências são o aumento do índice de violência na cidade e o aumento das ocorrências com relação a isso é porque alguns trabalhadores estão procurando "formas alternativas" para sobreviver. Ameaças estas que podem ligar a vitimização ao comportamento desviante.

Essa particularidade, aliada a todas as perdas sofridas pelas vítimas, também exacerba outro traço da vitimização ambiental: a percepção da vida sem futuro. Os olhos de Bárbara se perderam no vazio ao ser perguntado como ela se via no futuro: "eu nem sei. Eu espero que o meu futuro seje pra bem ou melhor ainda". Tomas, sobre o futuro, ressalta que "só chegando pra ver. Nunca vai ser o mesmo. A liberdade nunca vai ser a mesma". E da justiça, pensa que ganhar o que é seu de direito já é o bastante, "porque punição pra poderoso pode até ter, mas eu não acredito não". Carlos e Joaquim veem o futuro como incerto, mas têm esperanças. Domingos não vê um bom futuro para a

47 SOLINÍS, Germán. O que é o território ante o espaço? In: RIBEIRO, Maria Teresa Franco; MILANI, Carlos Roberto Sanchez (Org.). Compreendendo a complexidade socioespacial contemporânea: o território como categoria de diálogo interdisciplinar. Salvador: EDUFBA: 2009. p. 278.

48 Segundo reportagem especial da Câmara Federal dos Deputados, em abril de 2017, o desemprego em Mariana bateu recorde: $23 \%$ da população. A paralisação das atividades da mineradora Samarco provocou o desemprego de 13 mil pessoas na cidade. Deste total, 8 mil eram diretamente ligadas à mineração. Outras cinco mil trabalhavam no comércio e empresas locais que dependiam da economia gerada pela atividade. 
COLOGNESE, Mariângela Matarazzo Fanfa. O caso Samarco: vitimização ambiental e dano social corporativo no cenário de Mariana - uma investigação empírica a partir da perspectiva das vítimas (PARTE II). Revista Eletrônica Direito e Política, Programa de Pós-Graduação Stricto Sensu em Ciência Jurídica da UNIVALI, Itajaí, v.13, n.3, $3^{\circ}$ quadrimestre de 2018. Disponível em: www.univali.br/direitoepolitica - ISSN 1980-7791

cidade e pensa ser muito velho para pensar nisso: "tinha que ter investido antes. Olhar o futuro. O minério vai acabar, o dinheiro vai acabar". Joaquina não se vê no futuro. Conta que conseguia fazer planos quando estava "dentro do que era meu. Eu nem me vejo no futuro, eu penso no futuro pros meus filhos que eu não posso deixar de pensar, mas eu não me vejo. O que vai ser de mim, como que vai ser?".

Nesse contexto, outra face da vitimização ambiental se revela: a apatia social. Carlos refere que o final de semana na cidade é a pior coisa que existe para ele: "porque durante a semana eu vejo alguém e final de semana tá todo mundo em casa, você não vê ninguém, tão tudo pra tudo quanto é lado aqui em Mariana". Joaquina conta que seu filho fica o dia inteiro sozinho, não tem liberdade para brincar, porque não pode confiar em deixar ele na rua como em Bento. Explica que tem medo da cidade, das pessoas, de acidentes, de sequestro. "Hoje você tem que ficar numa casa com muro, com cerca elétrica, com medo dos outros passando na rua". Bárbara se pergunta "até quando vamos viver nessa vida?" Conta que fica olhando na janela, para baixo, e não vê nada: "O barulho hoje é outro. É de silêncio. Acabou".

Por conseguinte, o dano significa, para as vítimas, a perda do território e do sentido de existência individual e coletiva, a privação causada pelo decréscimo dos seus patrimônios e das suas receitas, e pela imposição de vida na cidade. Também significa o medo quanto às implicações futuras que a exposição à lama e a poeira pode trazer, bem como o tempo prolongado na cidade pode implicar no sentido de pertencimento a uma comunidade específica.

Com relação aos aspectos da vitimização, os mais expressivos significados para as vítimas são aqueles procedentes da alienação socioespacial: o medo da cidade, a discriminação, o preconceito, a marginalização, a criminalidade, a desagregação social e cultural, e a apatia social. Tudo isso decorrente do alijamento de todas essas pessoas de seu modo de vida e da privação dos laços comunitários. Assim, considera-se a multidimensionalidade dos efeitos em cada indivíduo ou grupos de indivíduos e a grave violação de direitos humanos, especialmente aqueles de uma gama de vítimas que tiveram direitos humanos fundamentais vulnerados.

$\mathrm{Na}$ perspectiva do dano social (social harm) entende-se que o conteúdo do portfólio criminológico deveria ser determinado pelos resultados substantivos das ações, mais do que de seu status legal.

A abordagem da lesão demanda uma matriz de resultados que habilita à identificação de ações que são análogas em suas 
COLOGNESE, Mariângela Matarazzo Fanfa. O caso Samarco: vitimização ambiental e dano social corporativo no cenário de Mariana - uma investigação empírica a partir da perspectiva das vítimas (PARTE II). Revista Eletrônica Direito e Política, Programa de Pós-Graduação Stricto Sensu em Ciência Jurídica da UNIVALI, Itajaí, v.13, n.3, $3^{\circ}$ quadrimestre de 2018. Disponível em: www.univali.br/direitoepolitica - ISSN 1980-7791

consequências a atos definidos como ilegais ou desviantes, incluindo aqueles que não são (ainda) o alvo tanto do controle legal como de uma aprovação social generalizada ${ }^{49}$.

Assim sendo, o reconhecimento como vítimas de danos provocados por ações e omissões em razão de interesses políticos, econômicos e corporativos é um fator extremamente relevante para o estudo do fenômeno desde a perspectiva de dano.

Trazer esses danos e suas peculiaridades para o campo de visão pode contribuir para que as vítimas e suas características multifacetadas se tornem visíveis. Trata-se não só de perceber a inadequação e ineficácia do direito penal para a prevenção dos danos sociais e ambientais. A amplitude de tais danos, além de revelar seu caráter de irreversibilidade nos traz de volta para a primeira lição e uma das conclusões principais desta pesquisa: a ideia de que a perspectiva de danos sociais pode ser relevante para a criminologia como um todo, e não apenas a parte do que incide sobre "crimes" ambientais.

É possível e desejável, para reconhecer uma perspectiva de danos sociais em criminologia, não apenas uma abordagem política ou moral que se preocupe com o meio ambiente, mas como uma ciência social ecológica e politicamente informada. Se na maioria dos sistemas de justiça penal, a vítima criminal ainda enfrenta obstáculos consideráveis para o reconhecimento e a participação no processo de justiça, os desafios são ainda maiores em termos de vítimas ambientais. Em consequência, a vítima ambiental está largamente ausente dos discursos públicos, tanto na retórica política circundante, em geral, e de fato da maioria das discussões acadêmicas sobre o tema.

\section{CONSIDERAÇÕES FINAIS}

De fato, o verdadeiro problema para vítimas ambientais não é somente quando está em causa a definição do que é legal ou ilegal. É um problema cultural e a literatura vitimológica está repleta de exemplos de mudanças culturais efetuadas nos sistemas de justiça criminal ao longo do tempo. Refiro-me especialmente as vítimas de violência doméstica, de violência sexual, de abuso de poder, as crianças e os adolescentes, e os idosos. Com relação às vítimas ambientais existe uma lacuna.

A vitimização ambiental demonstra uma série de problemas sociais, legais e psicológicos após os impactos imediatos do dano ambiental sofrido. Forçadas a migrar (desterritorialização), as populações de Bento Rodrigues e Paracatu de Baixo enfrentam a

49 MICHALOWSKI, Raymond. In search of 'state and crime' in state crime studies. In: CHAMBLISS; William J.; MICHALOWSKI, Raymond; KRAMER, Ronald (ed.) State Crime in Global Age. Devon-UK: Willan, 2010. p. 16. (Tradução nossa) 
COLOGNESE, Mariângela Matarazzo Fanfa. O caso Samarco: vitimização ambiental e dano social corporativo no cenário de Mariana - uma investigação empírica a partir da perspectiva das vítimas (PARTE II). Revista Eletrônica Direito e Política, Programa de Pós-Graduação Stricto Sensu em Ciência Jurídica da UNIVALI, Itajaí, v.13, n.3, $3^{\circ}$ quadrimestre de 2018. Disponível em: www.univali.br/direitoepolitica - ISSN 1980-7791

segregação socioespacial. Além disso, tanto essas vítimas diretas como as indiretas experimentam tensões econômicas e culturais semelhantes pela paralisação das atividades da Samarco. Isso ocorre como um resultado indireto de mudanças nas condições econômicas ou culturais. Tanto as vítimas diretas (aqueles que perderam suas terras ou modos de vida tradicionais) como as indiretas (comerciantes em geral e funcionários, terceirizados ou não, desligados da empresa) experimentam carências múltiplas causadas pela perda repentina de receitas.

A vitimização ambiental no caso de Mariana apresenta elementos de negação; a percepção do risco dispersa pela familiaridade com a mineração; a percepção distorcida do problema influenciada pelos discursos públicos que impõem e neutralizam a realidade; o estado de inércia dos atores sociais evitou que produzissem um ativismo capaz de agir preventivamente ao dano ocasionado; a percepção e consciência de estar sofrendo o problema faz emergir com força a questão da injustiça ambiental e a privação do direito de desfrutar um ambiente saudável; os danos estão relacionados a um grupo de vítimas portadoras de interesses conflitantes; o dano é causa de ações que não são taxadas como ilegais, levadas a cabo por uma corporação amparada na conduta omissiva do Estado; as vítimas, em um contexto isolado, se apresentaram pouco no processo, por isso o papel dos movimentos sociais é mais ativo, porque isoladamente os atingidos e as atingidas não têm poder político ou social frente às grandes corporações e ao próprio Estado.

As comunidades mais dependentes são mais tolerantes porque a indústria Ihes beneficia de várias maneiras. Isso afeta a postura regulamentar do Estado e também o engajamento popular. Em razão disso, a injustiça ambiental acaba ocorrendo, como no caso de Fundão, com o consentimento implícito daqueles suscetíveis de serem afetados negativamente por seus danos. A negação traduz muito bem esse "não ver" o que está bem diante dos olhos, porque os benefícios da indústria são "maiores". Isso mina qualquer reação potencialmente política e crítica para o que são as práticas ambientais objetivamente destrutivas. Ressalto que ao evidenciar os elementos de negação tanto das vítimas como da parte socialmente privilegiada (empresa e poder público) não quero estabelecer uma responsabilidade coletiva. Essas constatações são um expediente que auxilia na compreensão do fenômeno e um instrumento para lidar com ele.

Quanto mais remota e marginal a área explorada e quanto mais dependente da mineração tornarem-se essas comunidades economicamente, há menos probabilidade de uma regulamentação adequada, da atuação estatal efetiva, da mobilização social e da 
COLOGNESE, Mariângela Matarazzo Fanfa. O caso Samarco: vitimização ambiental e dano social corporativo no cenário de Mariana - uma investigação empírica a partir da perspectiva das vítimas (PARTE II). Revista Eletrônica Direito e Política, Programa de Pós-Graduação Stricto Sensu em Ciência Jurídica da UNIVALI, Itajaí, v.13, n.3, $3^{\circ}$ quadrimestre de 2018. Disponível em: www.univali.br/direitoepolitica - ISSN 1980-7791

politização das questões. De um lado estão o poder e o lucro como principais determinantes nesse debate e de outro estão as pessoas mais propensas ao sofrimento com a mudança radical da terra: as minorias marginalizadas e afetadas pela degradação ambiental.

Além disso, tal como acontece com as vítimas criminais, há questões persistentes de identificação, reconhecimento, participação, correção, compensação e reparação que dizem respeito às questões de justiça com as vítimas ambientais. É necessário, por isso, conhecer o impacto dos danos para obter uma imagem de como eles podem ser tratados no âmbito legal e político existente, e do potencial em termos de direitos humanos para proteger e reconceitualizar direitos em relação ao meio ambiente.

A mobilização política capitaneada pelos movimentos sociais significa um start para o diálogo e a reavaliação das ações do poder público e da Samarco. Para as vítimas representa, sobretudo, resistência ao assujeitamento produzido pelas estruturas de poder político e econômico. Essa resistência perante os gigantes da mineração nacional e mundial é essencial para informar uma agenda política mais ampla de mudanças sociais mudança conduzida, não por poderosas elites políticas e jurídicas, mas pela resistência da sociedade civil organizada contra as estruturas corruptas e violentas de governo e corporação. Além disso, é fundamental para exigir a participação das populações atingidas no processo decisório ambiental, na avaliação dos riscos e na prevenção dos danos.

A práxis dos delitos contra o meio ambiente aponta que se tratam mais de uma direção estatal da economia do que uma atribuição individual de culpabilidade, porque o Estado não consegue administrar os problemas gerados pelas atividades ambientalmente nocivas, seja porque não tem capacidade para fiscalizar quando as regulamenta, seja porque ao impor uma regulamentação mais dura pode causar a evasão de forças produtivas, o que prejudica sobremaneira a sua presença direta na economia como sujeito produtor de bens e de serviços.

A Lei no $9.605 / 98^{50}$, embora seja uma resposta às exigências de nossos tempos, tem-se mostrado inefetiva na proteção do meio ambiente. Isso porque não se pode invocar um direito que atua repressivamente para proteger um bem que exige toda uma organização jurídica guiada pela ideia precaução e de prevenção. Adaptar o direito penal para a tutela de bens jurídicos difusos, como é o caso do meio ambiente, tem um óbice grave e

${ }^{50}$ BRASIL. Lei no 9.605 de 12 de fevereiro de 1998. Dispõe sobre as sanções penais e administrativas derivadas de condutas e atividades lesivas ao meio ambiente, e dá outras providências. 
COLOGNESE, Mariângela Matarazzo Fanfa. O caso Samarco: vitimização ambiental e dano social corporativo no cenário de Mariana - uma investigação empírica a partir da perspectiva das vítimas (PARTE II). Revista Eletrônica Direito e Política, Programa de Pós-Graduação Stricto Sensu em Ciência Jurídica da UNIVALI, Itajaí, v.13, n.3, $3^{\circ}$ quadrimestre de 2018. Disponível em: www.univali.br/direitoepolitica - ISSN 1980-7791

incontornável, pois independementemente das contorções dogmáticas que sejam feitas para tanto, o sistema está estruturalmente montado para não funcionar, ele opera de maneira oposta, reproduzindo desigualdade e violência. Por outro lado, o direito a um meio ambiente saudável pressupõe igualdade e democracia.

Não é objetivo trazer à tona controvérsias dogmáticas na proteção do meio ambiente, a exemplo de delitos de perigo abstrato, normas penais em branco, responsabilidade penal da pessoa jurídica, bem jurídico ambiental, crimes de acumulação. Se assim o fizesse, eu estaria me distanciando do objeto principal da pesquisa, que são as vítimas ambientais, e da opção metodológica que se atrela essencialmente à teorização de um fenômeno social e não de uma análise de conflitos dogmáticos.

O método de estudo aqui adotado propiciou o alargamento do campo de conhecimento e a percepção, por meio da comparação das evidências com as ideias de outros estudiosos, como e onde esses danos residem, em que contexto eles se desenvolvem e são facilitados/acobertados/invisibilizados. Os conceitos esclarecem as categorias teóricas criadas e o modo como este estudo transcende ou questiona as ideias predominantes no campo criminológico e vitimológico. Mais que isso, essa pesquisa pretende ser fonte de transformação resolutiva, ou seja, lançar a frente o desafio da construção de um conhecimento que supere suas próprias limitações para minimizar o grande hiato que existe entre a produção científica sobre o tema e ações sociais e políticas efetivas para enfrentá-lo.

A realidade vivida e contada pelas próprias vítimas ambientais influencia a busca por alternativas. Elas se encontram na superação de limites epistemológicos da criminologia que, ao deixar de focar no crime, desvia a atenção para os danos muito mais extensos. A visibilização das vítimas ambientais está na convergência dos direitos já conquistados pelas vítimas criminais com o reconhecimento como vítimas de danos causados pelos poderes econômicos, políticos e corporativos. São esses fatores extremamente relevantes para o estudo do fenômeno desde uma perspectiva de dano, para que instrumentos jurídicos de tratamento, formas de resolução de conflitos e de respostas institucionais a essa espécie de vitimização se pautem nos seus resultados.

\section{REFERÊNCIAS DAS FONTES CITADAS}

BOEIRA, Luis Francisco Simões; COLOGNESE, Mariângela Matarazzo Fanfa. O papel da criminologia diante da devastação ambiental causada pela criminalidade dos poderosos. Revista Eletrônica Direito e Política, Programa de Pós-Graduação Stricto Sensu em Ciência Jurídica da UNIVALI, Itajaí, v.12, n.1, $1^{\circ}$ quadrimestre de 2017. Disponível em: 
COLOGNESE, Mariângela Matarazzo Fanfa. O caso Samarco: vitimização ambiental e dano social corporativo no cenário de Mariana - uma investigação empírica a partir da perspectiva das vítimas (PARTE II). Revista Eletrônica Direito e Política, Programa de Pós-Graduação Stricto Sensu em Ciência Jurídica da UNIVALI, Itajaí, v.13, n.3, $3^{\circ}$ quadrimestre de 2018. Disponível em: www.univali.br/direitoepolitica - ISSN 1980-7791

<https://siaiap32.univali.br/seer/index.php/rdp/article/viewFile/10405/5822>. Acesso em: $11 \mathrm{dez} .2017$.

BOHEM, Camila. Além do Rio Doce, águas subterrâneas da bacia também estão contaminadas. EBC - Agência Brasil, São Paulo, 15 abr. 2017. Disponível em: <http://agenciabrasil.ebc.com.br/geral/noticia/2017-04/alem-do-rio-doce-aguassubterraneas-da-bacia-tambem-estao-contaminadas>. Acesso em: 16 mai. 2017.

BRASIL. Lei no 9.605 de 12 de fevereiro de 1998. Dispõe sobre as sanções penais e administrativas derivadas de condutas e atividades lesivas ao meio ambiente, e dá outras providências. Disponível em: <http://www.planalto.gov.br/ccivil_03/leis/L9605.htm>. Acesso em: 16 jun. 2016.

Lei no 12.608, de 10 de abril de 2012. Institui a Política Nacional de Proteção e Defesa Civil - PNPDEC; dispõe sobre o Sistema Nacional de Proteção e Defesa Civil - SINPDEC e o Conselho Nacional de Proteção e Defesa Civil - CONPDEC; autoriza a criação de sistema de informações e monitoramento de desastres; altera as Leis $\mathrm{n}^{\circ} \mathrm{s}$ 12.340 , de $1^{\circ}$ de dezembro de 2010,10.257, de 10 de julho de 2001, 6.766, de 19 de dezembro de 1979, 8.239, de 4 de outubro de 1991, e 9.394, de 20 de dezembro de 1996; e dá outras providências. Disponível em: <http://www2.camara.leg.br/legin/fed/lei/2012/lei-12608-10-abril-2012-612681-normapl.html>. Acesso em: 16 jun. 2016.

. Resolução no 466, 12 de dezembro de 2012. Dispõe sobre as diretrizes e as normas regulamentadoras de pesquisa envolvendo seres humanos. Conselho Nacional de Saúde. $\quad 2012.20$ Brasília, 20 : <http://conselho.saude.gov.br/resolucoes/2012/Reso466.pdf>. Acesso em: 20 mai. 2016.

CÂMARA DOS DEPUTADOS. Tragédia em Mariana: como está a cidade histórica, um ano depois. 2016. Disponível em: <http://www2.camara.leg.br/camaranoticias/radio/materias/REPORTAGEMESPECIAL/521425-TRAGEDIA-EM-MARIANA-COMO-ESTA-A-CIDADE-HISTORICA,-UMANO-DEPOIS-BLOCO-10.html>. Acesso em: 12 jun. 2017.

COHEN, Stanley. States of Denial: Knowing about Atrocities and Suffering. Cambridge, UK: Polity Press, 2001.

COORDENADORIA DAS PROMOTORIAS DE JUSTIÇA DE DEFESA DO PATRIMÔNIO CULTURAL E TURÍSTICO DE MINAS GERAIS - CPPC/MPMG. MPMG firma Termo de Compromisso com a Samarco para proteger e evitar maiores danos aos bens culturais remanescentes em distritos de Mariana. 2015. Disponível em: <http://www.mpmg.mp.br/areas-de-atuacao/defesa-do-cidadao/patrimonio-historico-ecultural/noticias/mpmg-firma-termo-de-compromisso-com-a-samarco-para-proteger-eevitar-maiores-danos-aos-bens-culturais-remanescentes-em-distritos-demariana.htm\#.WV_ijYjyvIU>. Acesso em: 26 jun. 2017.

\section{COUTO, Douglas. Conselho do Patrimônio define pelo tombamento de Bento e Paracatu. $2016 . \quad$ Disponível em:} <http://www.pmmariana.com.br/noticia/3347/conselho-do-patrimonio-define-pelotombamento-de-bento-e-paracatu>. Acesso em: 20 jun. 2017.

FERRAZ, Lucas; PRADO, Avener. O caminho da lama. Folha de São Paulo, São Paulo, 2 dez. 2015. Disponível em: <http://temas.folha.uol.com.br/o-caminho-da-lama/capitulo$1 /$ mineracao-abre-cratera-faz-pico-de-montanha-sumir-e-cria-bairros-fantasmas-em- 
COLOGNESE, Mariângela Matarazzo Fanfa. O caso Samarco: vitimização ambiental e dano social corporativo no cenário de Mariana - uma investigação empírica a partir da perspectiva das vítimas (PARTE II). Revista Eletrônica Direito e Política, Programa de Pós-Graduação Stricto Sensu em Ciência Jurídica da UNIVALI, Itajaí, v.13, n.3, $3^{\circ}$ quadrimestre de 2018. Disponível em: www.univali.br/direitoepolitica - ISSN 1980-7791

regiao-de-minas.shtml>. Acesso em: 27 nov. 2016.

GLASER, Barney G.; STRAUSS, Anselm L. Awareness of dying. Chicago: Aldine, 1965.

The Discovery of grounded theory. Chicago: Aldine, 1967.

INSTITUTO BRASILEIRO DO MEIO AMBIENTE E DOS RECURSOS NATURAIS RENOVÁVEIS - IBAMA. Laudo Técnico Preliminar: Impactos ambientais decorrentes do desastre envolvendo o rompimento da barragem de Fundão, em Mariana, Minas Gerais. 2015. Disponível

em: <http://www.ibama.gov.br/phocadownload/noticias_ambientais/laudo_tecnico_preliminar .pdf>. Acesso em 01 nov. 2016.

KATZ, Ilana; BRUM, Eliane; DUNKER, Christian. Refugiados de Belo Monte. 2016. Disponível em: <https://www.catarse.me/refugiadosdebelomonte>. Acesso em: 9 mai. 2018.

MARSHALL, George. A psicologia da negação. In: DREYER, Lilian. Augusto Carneiro: depois de tudo um ecologista. Buqui Livros Digitais, 2014.

MEIRELLES, Hely Lopes. Direito administrativo brasileiro. 11. ed. São Paulo: Revista dos Tribunais, 1985.

MICHALOWSKI, Raymond. In search of 'state and crime' in state crime studies. In: CHAMBLISS; William J.; MICHALOWSKI, Raymond; KRAMER, Ronald (ed.) State Crime in Global Age. Devon-UK: Willan, 2010.

MILL, John Stuart. On Liberty. 4. ed. Londres: Longman, Roberts, \& Green Co., 1859.

MOVIMENTO DOS ATINGIDOS POR BARRAGENS - MAB. Foz do Rio Doce apresenta quantidade de metais pesados similar ao período do rompimento. 2017. Disponível em: <http://www.mabnacional.org.br/noticia/foz-do-rio-doce-apresentaquantidade-metais-pesados-similar-ao-odo-do-rompimento>. Acesso em 16 jun. 2017.

NATALI, Lorenzo. Criminology, victimización medioambiental y social harm - El caso de Huelva (España). Revista Crítica Penal y Poder. OSPDH, n. 7, pp. 5-34, set., 2014.

SAMPAIO, José Adércio Leite. As deficiências do plano de ação emergencial das barragens no Brasil. Revista Brasileira de Direito, v.12, n. 2, pp. 7-17, jul./dez., 2016. Disponível em: <https://seer.imed.edu.br/index.php/revistadedireito/article/download/1313/1026>. Acesso em: 3 jul. 2017.

SCHWENDINGER, Herman; SCHWENDINGER, Julia. Defensores da ordem ou guardiães dos direitos humanos? In: TAYLOR, Ian; WALTON, Paul; YOUNG, Jock. Criminologia crítica. Rio de janeiro: Edições Graal, 1988.

SOLINÍS, Germán. O que é o território ante o espaço? In: RIBEIRO, Maria Teresa Franco; MILANI, Carlos Roberto Sanchez (Org.). Compreendendo a complexidade socioespacial contemporânea: o território como categoria de diálogo interdisciplinar. Salvador: EDUFBA: 2009.

SILVA, Fabiano Reis. A paisagem do quadrilátero ferrífero, MG: potencial para o uso turístico da sua geologia e geomorfologia. 2007. 144p. Dissertação (Mestrado em Geografia) - Departamento de Geografia, Universidade Federal de Minas Gerais, Belo Horizonte, MG, $2007 . \quad$ Disponível em: <http://www.bibliotecadigital.ufmg.br/dspace/bitstream/handle/1843/MPBB- 
COLOGNESE, Mariângela Matarazzo Fanfa. O caso Samarco: vitimização ambiental e dano social corporativo no cenário de Mariana - uma investigação empírica a partir da perspectiva das vítimas (PARTE II). Revista Eletrônica Direito e Política, Programa de Pós-Graduação Stricto Sensu em Ciência Jurídica da UNIVALI, Itajaí, v.13, n.3, $3^{\circ}$ quadrimestre de 2018. Disponível em: www.univali.br/direitoepolitica - ISSN 1980-7791

79DNDW/disserta_o_fabiano_reis_silva.pdf;jsessionid=F0B1B652F9ADC517BA590858D F2EEF8A ?sequence=1>. Acesso em: 30 mai. 2017.

SISTEMA INTEGRADO DE INFORMAÇÃO AMBIENTAL - SIAM, MG. RADA: Relatório de Avaliação do Desempenho Ambiental. 2013. Disponível em: <http://www.siam.mg.gov.br/siam/lc/2013/0001519840952013/7086862013.pdf>.

Acesso em: 9 mai. 2017.

SKINNIDER, Eileen. Victims of Environmental Crime - Mapping the Issues. Vancouver: International Centre for Criminal Law Reform and Criminal Justice Policy, 2011.

TAVARES, Ruzimar Batista. Atividades extrativas minerais e seus corolários na bacia do alto ribeirão do Carmo: da descoberta do ouro aos dias atuais. Ouro Preto: UFOP, 2006.

VORMITTAG, Evangelina da Motta Pacheco Alves de Araujo; OLIVEIRA, Maria Aparecida de; RODRIGUES, Cristina Guimarães; GLERIANO, Josué Souza. Avaliação dos riscos em saúde da população de Barra Longa/MG afetada pelo desastre. Instituto Saúde e Sustentabilidade e Greenpeace, 2017. Disponível em: $<$ http://www.saudeesustentabilidade.org.br/wpcontent/uploads/2017/04/RELAT\%C3\%93RIO_GREENPEACE_30.03.17_FINAL.pdf>. Acesso em: 8 mai. 2018.

WILLIAMS, Christopher. Doing International Research: Global and Local Methods. London: Sage Publications Ltd, 2015.

2013.

Environmental victims - new risks, new injustices. New York: Earthscan,

Recebido em: 10/08/2018

Aprovado em: 20/08/2018 